\title{
Vesicular and Plasma Membrane Transporters for Neurotransmitters
}

\author{
Randy D. Blakely ${ }^{1}$ and Robert H. Edwards ${ }^{2}$ \\ ${ }^{1}$ Department of Pharmacology and Psychiatry, Vanderbilt University School of Medicine, Nashville, \\ Tennessee 37232-8548 \\ ${ }^{2}$ Departments of Neurology and Physiology, UCSF School of Medicine, San Francisco, \\ California 94143 \\ Correspondence: robert.edwards@ucsf.edu
}

\begin{abstract}
The regulated exocytosis that mediates chemical signaling at synapses requires mechanisms to coordinate the immediate response to stimulation with the recycling needed to sustain release. Two general classes of transporter contribute to release, one located on synaptic vesicles that loads them with transmitter, and a second at the plasma membrane that both terminates signaling and serves to recycle transmitter for subsequent rounds of release. Originally identified as the target of psychoactive drugs, these transport systems have important roles in transmitter release, but we are only beginning to understand their contribution to synaptic transmission, plasticity, behavior, and disease. Recent work has started to provide a structural basis for their activity, to characterize their trafficking and potential for regulation. The results indicate that far from the passive target of psychoactive drugs, neurotransmitter transporters undergo regulation that contributes to synaptic plasticity.
\end{abstract}

$T^{\mathrm{h}}$ he speed and potency of synaptic transmission depend on the immediate availability of synaptic vesicles filled with high concentrations of neurotransmitter. In this article, we focus on the mechanisms responsible for packaging transmitter into synaptic vesicles and for reuptake from the extracellular space that both terminates synaptic transmission and recycles transmitter for future rounds of release. Collectively, we refer to this entire process as the neurotransmitter cycle.

The recycling of neurotransmitter illustrates a general, conceptual problem for the mechanism of vesicular release. At the plasma mem- brane, more active reuptake should help to replenish the pool of releasable transmitter, but may also reduce the extent and duration of signaling to the postsynaptic cell. Conversely, loss of reuptake increases the activation of receptors but results in the depletion of stores (Jones et al. 1998). At the vesicle, steeper concentration gradients release more transmitter per vesicle but reduce the cytosolic transmitter available for refilling, whereas more shallow gradients facilitate refilling but reduce the transmitter available for release. The way in which the nerve terminal balances these competing factors thus has profound consequences for synaptic transmission.

Editors: Morgan Sheng, Bernardo Sabatini, and Thomas Südhof

Additional Perspectives on The Synapse available at www.cshperspectives.org

Copyright (C) 2012 Cold Spring Harbor Laboratory Press; all rights reserved; doi: 10.1101/cshperspect.a005595

Cite this article as Cold Spring Harb Perspect Biol 2012;4:a005595 
R.D. Blakely and R.H. Edwards

\section{NEUROTRANSMITTER SYNTHESIS AND TRANSPORT INTO SECRETORY VESICLES}

The ability of vesicles to concentrate neurotransmitter was suspected by Bernard Katz and coworkers when identifying quantal events associated with the release of acetylcholine $(\mathrm{ACh})$ at the neuromuscular junction. The subsequent identification of synaptic vesicles by electron microscopy then provided a structural basis for this phenomenon (Katz 1971). Julius Axelrod, Arvid Carlsson, and others extended the concept of vesicular storage, finding that radiolabeled catecholamines became "stabilized" after uptake (Carlsson 1963; Axelrod 1971).

The amount of neurotransmitter released per vesicle can also influence the postsynaptic response. The extent of vesicle filling is particularly important for volume transmission by neuromodulators such as monoamines, Ach, and neuropeptides, in which release often occurs at a distance from receptors. However, the amount of transmitter released per vesicle influences signaling even at classical synapses, where receptors lie immediately under the release site. Even high affinity NMDA receptors for glutamate are not saturated by the release of a single synaptic vesicle at many synapses (Mainen et al. 1999; McAllister and Stevens 2000), indicating the potential for changes in vesicle filling to influence synaptic transmission, particularly for lower affinity ionotropic receptors or $\mathrm{G}$ proteincoupled receptors outside the synapse. There are three major determinants of vesicle filling: the cytosolic concentration of transmitter, the $\mathrm{H}^{+}$electrochemical driving force across the vesicle membrane, and intrinsic properties of the vesicular transporter such as its ionic coupling.

\section{Neurotransmitter Biosynthesis}

The availability of cytosolic neurotransmitter depends on specific biosynthetic enzymes. The enzyme tyrosine hydroxylase has a rate-limiting role in catecholamine biosynthesis, and normally functions at a small fraction of its potential capacity because of allosteric feedback inhibition by L-Dopa and its downstream product dopamine (DA) (Zigmond et al. 1989). Phos- phorylation regulates tyrosine hydroxylase activity through modulation of this feedback inhibition, and the enzyme undergoes stringent regulation at transcriptional as well as posttranslational levels (Kaneda et al. 1991). Much less is known about the closely related enzyme tryptophan hydroxylase, which is involved in serotonin (5-hydroxyptryptamine, 5-HT) production. The biosynthetic enzyme for ACh, choline acetyltransferase (ChAT), has similarly received little attention, but the gene resides at the same chromosomal locus as the vesicular ACh transporter (VAChT), and indeed shares some of the same promoters (Erickson et al. 1994; Cervini et al. 1995), indicating highly conserved, coordinate regulation of the two proteins. ChAT also appears to undergo regulation by phosphorylation (Dobranskyand Rylett 2005), but under most circumstances, the plasma membrane choline transporter (CHT) is thought to be rate-limiting (Ferguson et al. 2004; Sarter and Parikh 2005).

GABA production relies on two, distinct biosynthetic enzymes, glutamic acid decarboxylase (GAD) of $65 \mathrm{kD}$ and $67 \mathrm{kD}$. An autoantigen in diabetes, the $65 \mathrm{kD}$ isoform associates directly with vesicles through palmitoylation (Christgau et al. 1992), whereas the $67 \mathrm{kD}$ isoform is cytosolic. However, the $67 \mathrm{kD}$ isoform appears much more important for GABAergic neurotransmission than the $65 \mathrm{kD}$-animals lacking the $67 \mathrm{kD}$ isoform die shortly after birth because of cleft palate, but also show up to $80 \%$ reduction in GABA levels (Asada et al. 1997; Condie et al. 1997). In contrast, loss of the $65 \mathrm{kD}$ isoform has minimal effect on inhibitory neurotransmission. Surprisingly, the amplitudes of evoked and spontaneous inhibitory postsynaptic currents (IPSCs) show no difference from controls, but the knockouts show increased synaptic depression to sustained synaptic activation (Tian et al. 1999), raising the interesting possibility that vesicle filling might influence release probability.

Considering its general role in intermediary metabolism and protein synthesis, glutamate can be synthesized from multiple sources. However, the inability to regenerate most of these sources (such as $\alpha$-ketoglutarate from the tri- 
carboxylic acid cycle) would result in the depletion of glutamate stores by prolonged stimulation. For this reason, the glutamate released as a transmitter is generally considered to derive from glutamine, which can be regenerated from glutamate through the so-called glutamine-glutamate cycle (Fig. 1). In contrast to most other classical transmitters which undergo reuptake directly into the nerve terminal, glutamate appears to recycle indirectly: after uptake into astrocytes through the excitatory amino acid transporters (EAATs), glutamate is converted into glutamine by glutamine synthetase, then transferred back to neurons where it is converted to glutamate and ammonia through the action of glutaminase (Fig. 1) (Albrecht et al. 2007). Consistent with this cycle, inhibition of glutamine synthetase results in the shift of glutamate immunoreactivity from neurons to astrocytes in the retina (Pow and Robinson 1994).

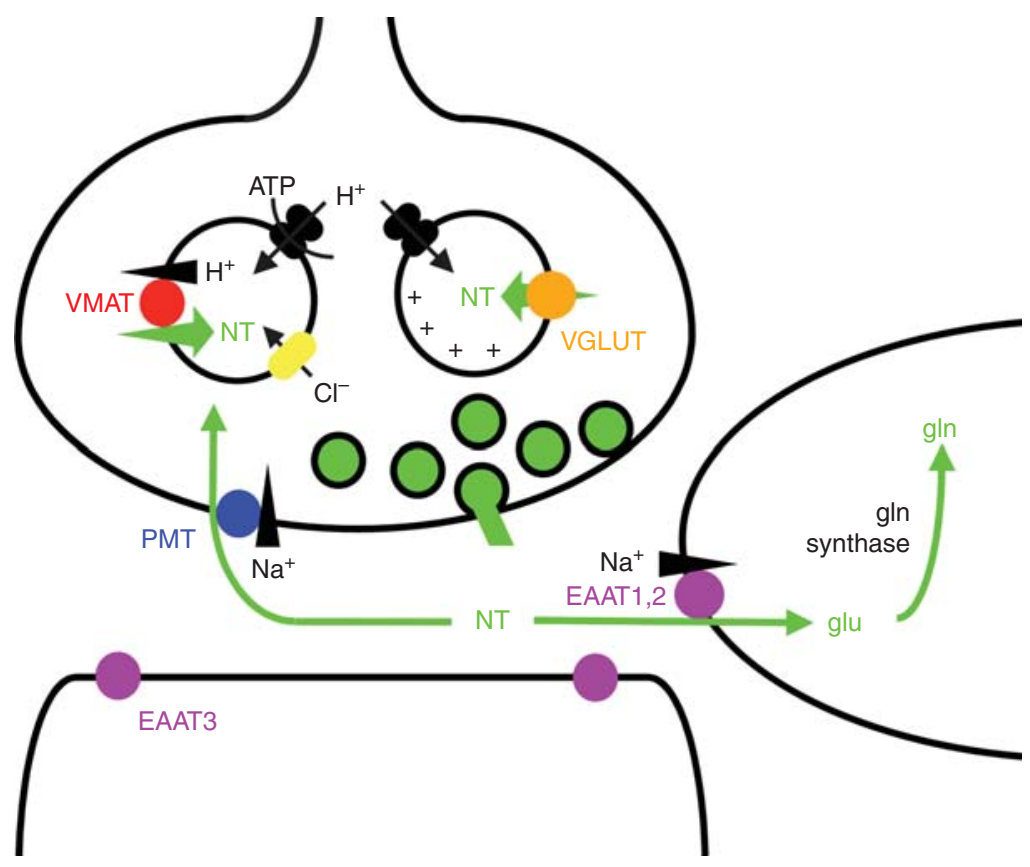

Figure 1. Role of plasma membrane and vesicular neurotransmitter transporters in synaptic transmission. After the exocytotic release from synaptic vesicles, neurotransmitter is transported back into the terminal by $\mathrm{Na}^{+}$and $\mathrm{Cl}^{-}$-dependent plasma membrane transporters (PMT), thereby regenerating the vesicular pools required to sustain release. In the case of glutamate, excitatory amino acid transporters (EAATs) are generally found on cells other than those directly involved in glutamate release; most of the uptake occurs into astrocytes, mediated by EAAT1 and 2, which do not couple stoichiometrically to the flux of $\mathrm{Cl}^{-}$. Nonetheless, other isoforms such as EAAT3 can be expressed by neurons, although generally not at presynaptic sites or not by glutamate neurons. The glutamate taken up by glia undergoes conversion to glutamine and is then thought to recycle to neurons through the system $\mathrm{N}$ transporters expressed by glia and the system A transporters expressed by neurons, with conversion back to glutamate by phosphate-activated glutaminase (PAG) within neurons. Synaptic vesicles fill with neurotransmitter through a process driven by the vacuolar-type $\mathrm{H}^{+}$-ATPase. However, different transmitters depend on different components of the $\mathrm{H}^{+}$electrochemical gradient produced by this pump. The vesicular monoamine transporter (VMAT) and closely related vesicular acetylcholine transporter depend primarily on the chemical component, $\Delta \mathrm{pH}$, whereas vesicular glutamate transporters (VGLUTs) depend predominantly on the membrane potential, $\Delta \psi$. The entry of anions such as $\mathrm{Cl}^{-}$(but also glutamate) promote the formation of $\Delta \mathrm{pH}$ by dissipating $\Delta \psi$ and hence allowing the $\mathrm{H}^{+}$pump to generate $\Delta \mathrm{pH}$, although the factors that promote $\Delta \psi$ have remained unexplored. 
The identification and characterization of system $\mathrm{N}$ and A transporters has suggested a mechanism for the transfer of glutamine from astrocyte to neuron (Fig. 1). The system $\mathrm{N}$ transporters SN1 and SN2 exchange $1 \mathrm{Na}^{+}$and 1 glutamine for $1 \mathrm{H}^{+}$, resulting in electroneutrality (Chaudhry et al. 1999). As a result, they depend only on the $\mathrm{Na}^{+}$gradient across the plasma membrane (not the membrane potential) and hence produce a very shallow gradient of glutamine that enables efflux simply by lowering the extracellular concentration of glutamine (Chaudhry et al. 1999; Broer et al. 2002). In contrast, the system A transporters SA (or SAT, SNAT) 1-3 couple the movement of neutral amino acids such as glutamine only to the flux of $\mathrm{Na}^{+}$, and hence depend on membrane potential as well as the $\mathrm{Na}^{+}$gradient, producing much steeper concentration gradients that can take up into neurons the glutamine released by astrocytes (Chaudhry et al. 2002b). Interestingly, the system $\mathrm{N}$ and A transporters are closely related to each other in sequence, differ primarily in the coupling to $\mathrm{H}^{+}$, and presumably contribute to nitrogen metabolism by the liver through a similar cycle (Haussinger and Schliess 2007).

On the other hand, the physiological role of these transporters and even glutamine itself in excitatory transmission requires further characterization. Although some work has suggested that the system A inhibitor methylaminoisobutyric acid (MeAIB) can impair glutamatergic transmission (Armano et al. 2002), it has been very difficult to influence baseline synaptic transmission by depleting extracellular glutamine (Kam and Nicoll 2007). Increasing extracellular glutamine can increase glutamate release, but endogenous levels appear adequate to sustain release under normal conditions. Indeed, the most recent work indicates a role for the glutamine-glutamate cycle primarily under pathologic conditions, such as seizures (Tani et al. 2007), and we still do not know the actual role of different glial and neuronal glutamine transporters.

After uptake by the neuron, glutamine is converted to glutamate by the mitochondrial enzyme phosphate-activated glutaminase (Curthoys and Watford 1995), but we again under- stand little of its role in synaptic transmission. A knockout of the main isoform expressed in brain results in neonatal death because of impaired respiration, but baseline excitatory transmission appears normal, indicating the presence of an alternate biosynthetic pathway, presumably caused by expression of the other glutaminase isoform (Masson et al. 2006). Despite the normal mEPSC amplitude, knockout animals still show increased synaptic rundown in response to high frequency stimulation, indicating that the kidney/brain isoform nonetheless contributes to release.

We know little about the actual cytosolic concentration of most classical transmitters. Labeling with antibodies has suggested cytosolic levels of glutamate in the low millimolar range (Gundersen et al. 1995). The direct manipulation of cytosolic contents at the calyx of Held also suggests low millimolar concentrations of glutamate, and further indicates the potential for changes in vesicle filling to influence quantal size (Ishikawa et al. 2002). In the case of DA, the insertion of a carbon fiber electrode directly into the cell has enabled detection of cytosolic levels (Mosharov et al. 2003). In chromaffin cells, the concentrations of cytosolic catecholamine can reach $50 \mu \mathrm{M}$, but in midbrain DA neurons, endogenous levels are undetectable $(<0.1 \mu \mathrm{M})$ unless boosted with the biosynthetic precursor L-Dopa (Mosharov et al. 2009). However, these levels could be greatly affected by activity-dependent alterations in DA synthesis, as noted above. Furthermore, the psychostimulant amphetamine can quickly release DA from the cytosol through the plasma membrane DA transporter (DAT) prior to depleting intracellular vesicle stores, suggesting that sufficient intracellular DA may be available to support transporter-mediated DA efflux (Jones et al. 1998). Inhibition of the intracellular, metabolic enzyme monoamine oxidase (MAO) further increases cytosolic DA, suggesting that multiple mechanisms serve to balance the potential for cytoplasmic toxicity with the need for vesicle refilling. Indeed, transport into the cell as well as into the vesicle are additional, important determinants of cytosolic transmitter concentration (Torres et al. 2003b). 


\section{Proton Electrochemical Driving Force}

The transport of all classical transmitters into neurosecretory vesicles depends on a $\mathrm{H}^{+}$electrochemical driving force $\left(\Delta \mu_{\mathrm{H}+}\right)$ generated by the vacuolar $\mathrm{H}^{+}$-ATPase (Fig. 1). The $\mathrm{H}^{+}$ pump produces a $\Delta \mu_{\mathrm{H}+}$ similar in magnitude to if not greater than that achieved across the plasma membrane for $\mathrm{Na}^{+}, \mathrm{K}^{+}$, and $\mathrm{Cl}^{-}$, providing a similar force to drive transport. However, the actual concentrations of $\mathrm{H}^{+}$are many orders of magnitude lower: $\mathrm{pH} 7$ is $0.1 \mu \mathrm{M}$ $\mathrm{H}^{+}$whereas the other ions are in the high millimolar range. In contrast to the relatively stable ionic gradients across the plasma membrane, $\Delta \mu_{\mathrm{H}+}$ can thus be made and dissipated with the flux of many fewer $\mathrm{H}^{+}$, ideal for synaptic vesicles, which undergo repeated exocytosis and endocytosis that respectively dissipate and regenerate $\Delta \mu_{\mathrm{H}+}$.

The $\mathrm{H}^{+}$-ATPase uses the energy released by ATP hydrolysis to pump protons into the vesicle lumen. Composed of a membrane sector V0 and a peripheral sector $\mathrm{V} 1$ that resemble the F0 and F1 sectors of the mitochondrial ATP synthase, the vacuolar $\mathrm{H}^{+}$pump also uses a rotary mechanism (Forgac 2007). However, the two $\mathrm{H}^{+}$pumps function in different directions under physiological conditions, the vacuolar pump hydrolyzing ATP to move $\mathrm{H}^{+}$, whereas the mitochondrial ATP synthase uses $\mathrm{H}^{+}$flux to produce ATP. Interestingly, the V0 sector has also been implicated in membrane fusion. Mutations in the V0 but not V1 sector disrupt vacuole fusion in yeast, and because both of these impair vacuole acidification, it suggests a direct role for the V0 sector in fusion, independent of acidification (Bayer et al. 2003). Similarly, mutation of a neuron-specific al subunit of the Drosophila V0 sector affects the evoked release of transmitter, but not the amplitude of spontaneous release events, again suggesting a specific role in fusion independent of the acidification required for vesicle filling (Hiesinger et al. 2005), although the mechanism remains unclear.

We know little about the regulation of $\mathrm{V}$ ATPase activity, but much evidence suggests an indirect form of regulation by chloride (Fig. 1).
In the absence of $\mathrm{Cl}^{-}$, the ATPase can in fact transport very few $\mathrm{H}^{+}$because the development of a lumen-positive membrane potential $(\Delta \Psi)$ opposes the activity of the pump. Indeed, synaptic vesicles develop a $\mathrm{pH}$ gradient $(\Delta \mathrm{pH})$ only after the addition of an anion such as $\mathrm{Cl}^{-}$. Entry of the anion dissipates $\Delta \Psi$, secondarily activating the $\mathrm{H}^{+}$pump to produce $\Delta \mathrm{pH}$, and ATPase activity can increase several orders of magnitude in response to the addition of $\mathrm{Cl}^{-}$(Forgac 2007). It is also generally considered that intracellular members of the $\mathrm{ClC}$ channel family account for the entry of $\mathrm{Cl}^{-}$. However, it has become clear that many of the intracellular $\mathrm{ClCs}$, including the prototypic Escherichia coli protein, function as $\mathrm{Cl}^{-} / \mathrm{H}^{+}$exchangers rather than as channels (Accardi and Miller 2004; Picollo and Pusch 2005; Scheel et al. 2005), and although counterintuitive, this coupling increases $\Delta \mathrm{pH}$ (Novarino et al. 2010). Synaptic vesicles contain multiple $\mathrm{ClC}$ isoforms, and it remains unclear which-if anyof the ClCs confer the chloride flux required for synaptic vesicle acidification.

Anions other than $\mathrm{Cl}^{-}$may also play a role in synaptic vesicle acidification. In addition to ATP, which may promote monoamine uptake independent of its role as a substrate for the $\mathrm{H}^{+}$pump (Bankston and Guidotti 1996), glutamate itself acidifies vesicles. Indeed, multiple monoamine cell populations express a VGLUT isoform that appears to promote vesicle filling with monoamine, presumably because of an increase in $\Delta \mathrm{pH}$. DA neurons express VGLUT2 and the conditional inactivation of VGLUT2 in DA neurons reduces the effect of psychostimulants (Birgner et al. 2010) by impairing DA storage and release (Hnasko et al. 2010). Similarly, the loss of VGLUT3 from cholinergic interneurons in the striatum reduces ACh storage and release (Gras et al. 2008). However, glutamate appears to promote a more stable $\Delta \mathrm{pH}$ than $\mathrm{Cl}^{-}$, and the mechanism appears to reflect the stoichiometry of coupling by VGLUTs (Hnasko et al. 2010).

It is important to note that the glutamate released by monoamine neurons also serves to activate postsynaptic glutamate receptors, independent of its role in vesicle acidification and 
monoamine storage. As predicted from previous work showing glutamate responses to the stimulation of midbrain DA input to the striatum (Chuhma et al. 2004), the expression of channelrhodopsin specifically in DA or 5-HT neurons (which express high levels of VGLUT3 [Fremeau et al. 2002; Gras et al. 2002; Schafer et al. 2002]) has enabled the detection of robust glutamatergic responses in, respectively, the postsynaptic medium spiny or hippocampal neurons (Varga et al. 2009; Stuber et al. 2010; Tecuapetla et al. 2010). Habenula neurons similarly corelease glutamate and ACh, with drastically different postsynaptic effects (Ren et al. 2011). In general, the role of the two signals released by a single neuron remains unclear, but recent work has shown a role for differential release of ACh and GABA from the same retinal starburst amacrine cells involved in direction selectivity (Lee et al. 2010).

\section{Vesicular Neurotransmitter Transport}

The expression of $\Delta \mu_{\mathrm{H}+}$ as $\Delta \mathrm{pH}$ or $\Delta \Psi$ has particular significance for transmitter release because different vesicular transporters depend to differing extents on the two components of the gradient. Vesicular monoamine and ACh transport rely predominantly on $\Delta \mathrm{pH}$, vesicular glutamate transport primarily on $\Delta \Psi$, and GABA transport more equally on both chemical and electrical components of $\Delta \mu_{\mathrm{H}+}$ (Fig. 1). Consistent with these differences in bioenergetics, the vesicular monoamine and ACh transporters show close sequence similarity to each other, whereas the vesicular glutamate and GABA transporters comprise entirely distinct families.

Classical studies in chromaffin granules showed that vesicular monoamine transport involves the exchange of two lumenal protons for one cytosolic, protonated amine (Johnson et al. 1981; Knoth et al. 1981), and this stoichiometry accounts for the greater reliance on $\Delta \mathrm{pH}$ than $\Delta \Psi$. With a vesicle $\mathrm{pH} \sim 5.8$ and $\Delta \Psi \sim 60 \mathrm{mV}$, the stoichiometry in turn predicts monoamine gradients of up to $10^{5}$ (lumen relative to cytosol), consistent with the high concentrations achieved inside chromaffin granules.
There are two vesicular monoamine transporters (VMATs) in mammals-VMAT1 expressed by nonneural cells such as adrenal chromaffin cells, and VMAT2 by neurons. However, both isoforms recognize multiple monoamines as substrates, with a slightly higher apparent affinity for VMAT2 (Peter et al. 1994; Erickson et al. 1996). Consistent with this, VMAT2 is expressed by multiple central monoamine populations (Weihe et al. 1994; Peter et al. 1995).

The VMATs have a $\mathrm{Km}$ in the low to submicromolar range, whereas the vesicular ACh, GABA, and glutamate transporters all show $\mathrm{Kms}$ in the low millimolar range. This high apparent affinity may contribute to the robust VMAT activity detected by radiotracer flux assays. In addition, it presumably enables the VMATs to achieve maximal transport at low cytosolic levels of substrate. Indeed, the vesicular monoamine transporter was cloned on the basis of its ability to protect against the parkinsonian neurotoxin $\mathrm{MPP}^{+}$, presumably by sequestering the toxin inside secretory vesicles and away from its primary site of action in mitochondria (Liu et al. 1992). VMAT may similarly protect against the toxicity of endogenous DA, and a defect may contribute to the degeneration of DA neurons in Parkinson's disease (Caudle et al. 2007; Mosharov et al. 2009). However, many factors limit the accumulation of DA in the cytoplasm-in the absence of VMAT activity, the brain content of monoamines declines by $>90 \%-95 \%$ due in part to cytoplasmic metabolism by monoamine oxidase (Fon et al. 1997; Takahashi et al. 1997; Wang et al. 1997).

On the other hand, the VMATs have a relatively low Vmax, with an estimated rate of 5$20 /$ sec depending on the substrate (Peter et al. 1994). Vesicle filling may therefore limit monoamine release from neurons with high rates of firing. The loss of VMAT2 in mice causes neonatal lethality because of impaired movement and feeding (Fon et al. 1997; Takahashi et al. 1997; Wang et al. 1997). Little is known about the regulation of intrinsic VMAT activity and its role in monoamine release.

The vesicular ACh transporter (VAChT) resembles the VMATs in primary sequence (Alfonso et al. 1993), but shows a much higher 
Km (Parsons 2000). Despite this, it has a relatively slow turnover $\sim 1 / \sec$ (Varoqui and Erickson 1996). A large body of work has shown presynaptic regulation of quantal size at the neuromuscular junction (Van der Kloot 2003), possibly involving VAChT (Song et al. 1997; Lima Rde et al. 2010).

The vesicular GABA transporter (VGAT) recognizes both inhibitory transmitters GABA and glycine (Wojcik et al. 2006). Identified by genetic studies in C. elegans (McIntire et al. 1993b; McIntire et al. 1997), VGAT defined a family of proteins structurally unrelated to VMAT, consistent with a greater dependence on $\Delta \Psi$. Nonetheless, dependence on $\Delta \mathrm{pH}$ had suggested that VGAT still functions as a $\mathrm{H}^{+}$exchanger. Surprisingly, purified VGAT reconstituted into artificial membranes may require $\mathrm{Cl}^{-}$for active transport (Juge et al. 2009). Importantly, the $\mathrm{Cl}^{-}$is cotransported, and with a Hill coefficient of 2, predicting strong dependence on the $\mathrm{Cl}^{-}$gradient as well as $\Delta \Psi$.

VGAT has the lowest apparent affinity of any vesicular transporter $(\mathrm{Km} \sim 5 \mathrm{mM}$ for GABA, $\sim 25 \mathrm{mM}$ for glycine), and probably relies on high cytosolic concentrations of substrate produced either by GAD in the case of GABA or by the plasma membrane glycine transporter GLYT2 in the case of glycine (Gomeza et al. 2003a). Among the vesicular neurotransmitter transporters, VGAT is so far the only one known to require a specific sorting protein, identified in C. elegans as UNC-46, a lysosome-associated membrane protein (LAMP) family member (Schuske et al. 2007).

The VGLUTs depend on $\Delta \Psi$ to a greater extent than the other vesicular transporters (Fig. 1), and belong to a distinct family of transport proteins. Although originally identified as $\mathrm{Na}^{+}$dependent phosphate transporters, their localization to synaptic vesicles and glutamate uptake on heterologous expression indicated a role for the VGLUTs in vesicular glutamate transport (Bellocchio et al. 2000; Takamori et al. 2000). Disruption of the VGLUT genes in worms and mice has confirmed their role in synaptic glutamate release (Lee et al. 1999; Fremeau et al. 2004; Wojcik et al. 2004; Wallen-Mackenzie et al. 2006; Gras et al. 2008; Seal et al. 2008; Hnasko et al. 2010). Indeed, other members of the socalled type I phosphate transporter family also appear to recognize organic anions (Busch et al. 1996; Verheijen et al. 1999). However, the coupling mechanisms vary considerably among family members, with sialin using $\mathrm{H}^{+}$cotransport to drive the electroneutral efflux of sialic acid out of the lysosome (Morin et al. 2004; Wreden et al. 2005) whereas the VGLUTs and the more distantly related vesicular nucleotide transporter VNUT (Sawada et al. 2008) exchange rather than cotransport $\mathrm{H}^{+}$. Although inorganic phosphate does not inhibit glutamate uptake by the VGLUTs (Bellocchio et al. 2000), reconstitution of the purified transporter confers $\mathrm{Na}^{+}$-dependent phosphate transport (Juge et al. 2006). Even more remarkably, sialin, an electroneutral $\mathrm{H}^{+}$cotransporter, has been suggested to transport both glutamate and aspartate through a mechanism dependent on $\Delta \Psi$ (Miyaji et al. 2008). Because VGLUT1-3 recognize glutamate but not aspartate, it will be important to determine whether sialin in fact contributes to the evoked release of aspartate.

The VGLUTs also show at least two distinct interactions with $\mathrm{Cl}^{-}$. First, they show an uncoupled $\mathrm{Cl}^{-}$conductance that may influence vesicle acidification, as described above. This conductance would serve to dissipate the $\Delta \Psi$ that drives glutamate transport, but glutamate appears to inhibit this conductance (Bellocchio et al. 2000). Second, $\mathrm{Cl}^{-}$regulates vesicular glutamate transport through an allosteric mechanism. VGLUT activity shows a biphasic dependence on $\mathrm{Cl}^{-}$, with an optimum $\sim 2-10$ $\mathrm{mM}$. Although originally considered to reflect changes in the expression of $\Delta \mu_{\mathrm{H}+}$, it has become clear that $\mathrm{Cl}^{-}$operates independently of the driving force to influence intrinsic VGLUT activity (Hartinger and Jahn 1993; Wolosker et al. 1996; Juge et al. 2010). However, manipulation of cytosolic $\mathrm{Cl}^{-}$at the calyx of Held has remarkably little effect on quantal size (Price and Trussell, 2006), suggesting that vesicle filling in vivo may reflect the thermodynamic equilibrium reached by the system more than the kinetics of transport.

In the brain, VGLUT1-3 define neurons as glutamatergic, and show an almost mutually 
exclusive pattern of expression, particularly in adulthood. VGLUT1 is expressed by glutamatergic neurons in the hippocampus and cortex, VGLUT2 in thalamus and brainstem and VGLUT3 in scattered neurons often not associated with the release of glutamate. For example, VGLUT3 is expressed by a subset of GABAergic interneurons as well as cholinergic interneurons of the striatum and serotonergic raphe neurons (Fremeau et al. 2002; Gras et al. 2002, 2008; Amilhon et al. 2010). In these cells, glutamate transport by VGLUT3 (and by VGLUT2 in DA neurons) both promotes vesicle filling with the other transmitter, and its release activates postsynaptic receptors, as discussed above. Notably, a variety of neuronal populations express VGLUT2 or 3 transiently during development. In the cortex, transient expression of VGLUT2 presumably accounts for the appearance of a phenotype in VGLUT1 knockout mice only around two weeks after birth (Fremeau et al. 2004). In the auditory brainstem, transient expression of VGLUT3 also contributes to the strengthening and tonotopic refinement of synapses (Noh et al. 2010).

What difference in vesicle filling is conferred by the different VGLUT isoforms? The crude transport assays currently available reveal no clear difference in uptake activity. Rather, the isoforms appear to differ in trafficking. Although VGLUT1 and 2 are almost exclusively axonal, VGLUT3 localizes to dendrites as well as axons in a number of cell populations (Harkany et al. 2004). VGLUT1 contains two polyproline motifs that interact with proteins involved in endocytosis such as endophilin, and influence recycling of the transporter (Voglmaier et al. 2006). Such motifs presumably influence the sorting of VGLUTs to distinct endocytic pathways, and recent work suggests that these pathways may generate synaptic vesicles with a different probability of release (Weston et al. 2011).

\section{Regulation of Vesicular Transporters}

Despite the potential for vesicle filling to regulate quantal size, we still know little about the physiological role for regulation of vesicular transport activity. Regulation could occur at the level of the driving force, through changes in the expression of $\Delta \mu_{\mathrm{H}+}$ as $\Delta \mathrm{pH}$ or $\Delta \Psi$. Indeed, the differences in ionic coupling by different vesicular neurotransmitter transporters might be expected to require differences in the expression of $\Delta \mu_{\mathrm{H}+}$. However, recent work has shown that glutamatergic and GABAergic synaptic vesicles differ primarily in the expression of vesicular neurotransmitter transporter, i.e., VGLUT and VGAT (Gronborg et al. 2010).

Differences in the number of transporters per vesicle would influence the rate of vesicle filling, but not necessarily the equilibrium eventually achieved. Indeed, one VGLUT protein appears sufficient to fill a single synaptic vesicle (Daniels et al. 2006). VGLUT1 heterozygotes show no obvious deficit in synaptic transmission (Fremeau et al. 2004). On the other hand, behavioral differences were reported in heterozygous VGLUT mice (Leo et al. 2009; Schallier et al. 2009), suggesting that the transporter may become rate-limiting with higher levels of activity. In this regard, overexpression of VAChT can increase quantal amplitudes (Song et al. 1997), suggesting that in the cholinergic system as well, transporter expression can limit the rate of vesicular filling. The VGLUTs were also identified as activity-regulated genes ( $\mathrm{Ni}$ et al. 1994; Aihara et al. 2000), that along with VGAT show homeostatic changes in expression with altered neural activity (De Gois et al. 2005), providing circumstantial evidence for a role in regulation of transmitter release. However, the trafficking of neurotransmitter transporters also has great potential to influence their number on synaptic vesicles. Interestingly, psychostimulants have been shown to influence the localization and function of VMAT2 (Volz et al. 2007; Farnsworth et al. 2009).

A number of reports describe the regulation of vesicle filling by heterotrimeric $\mathrm{G}$ proteins, in particular Goo2 (Ahnert-Hilger et al. 1998; Holtje et al. 2003; Winter et al. 2005). Although the molecular mechanism of modulation remains uncertain, it may involve a direct interaction of G protein with neurotransmitter transporter (Winter et al. 2005; Brunk et al. 2006). 
Not All Transporters on Synaptic Vesicles Transport Substrates into the Vesicular Compartment

Several transporters found on synaptic vesicles cannot use vesicular ion and voltage gradients to concentrate solutes across vesicular membranes. The high-affinity, $\mathrm{Na}^{+}$and $\mathrm{Cl}^{-}$dependent, L-proline transporter (PROT) (Fremeau et al. 1992) resides on synaptic vesicles in a subset of terminals that release L-glutamate (Crump et al. 1999; Renick et al. 1999). Although little evidence supports a role for proline as neurotransmitter, PROT activity is easily detectable at the plasma membrane in brain synaptosomes $(\mathrm{Na}-$ dler 1987) where it may modulate glutamate release (Cohen and Nadler 1997a), glutamate receptor function (Cohen and Nadler 1997b), or perhaps ensure the availability of cytoplasmic glutamate for vesicular uptake and release (Atlante et al. 1996). A second example is the hemicholinium-sensitive, choline transporter $(\mathrm{CHT})$, $\mathrm{a} \mathrm{Na}^{+}$and $\mathrm{Cl}^{-}$-dependent transporter that provides for uptake of the precursor at the plasma membrane of cholinergic nerve terminals (Macintosh et al. 1956; Yamamura and Snyder 1972; Maire and Wurtman 1985). CHT localizes to a subset of VAChT-positive synaptic vesicles (Ferguson et al. 2003; Nakata et al. 2004). As with PROT, the vesicular location provides a mechanism for the coupling of choline transport to exocytotic transmitter release through coincident insertion of transporters into the plasma membrane.

\section{PLASMA MEMBRANE NEUROTRANSMITTER TRANSPORTERS}

All small molecule neurotransmitters require a mechanism to terminate signaling, and this usually involves transporter-mediated reuptake. Enzymatic conversion of ACh by acetylcholinesterase is perhaps the only exception to this rule. In many cases, neurotransmitter reuptake occurs into the terminal from which it was released, but in other instances, particularly for amino acid neurotransmitters, these molecules can be cleared by transporters located on astrocytes (Fig. 1) (Bergles et al. 1999) or even on terminals that release another neurotransmitter (Gresch et al. 1995; Zhou et al. 2005). After release, diffusion of neurotransmitter within the extracellular space is extremely rapid, with levels predicted to drop in milliseconds below the concentrations needed to activate receptors (Clements 1996), much faster than expected from the rate at which transporters can move neurotransmitters across the membrane $(\sim 1-10$ transfer events $/ \mathrm{sec})$. Thus, binding of neurotransmitters to their transporters ("buffering") is suspected to be just as or more important in clearing neurotransmitter than the actual transport process.

As with the concentrative uptake of neurotransmitter into vesicles, all plasma membrane neurotransmitter transporters use transmembrane ion or voltage gradients to energize the clearance process (Pastuszko et al. 1982; Zerangue and Kavanaugh 1996; Rudnick 1997). This is particularly important for the amino acid transmitters that exist at very high concentrations in the cytosol. In this case, transporters that only equilibrate substrate across the membrane would result in efflux rather than uptake. Plasma membrane neurotransmitter transporters thus rely on $\mathrm{Na}^{+}$and $\mathrm{K}^{+}$gradients across the plasma membrane established by the ubiquitous $\mathrm{Na}^{+} / \mathrm{K}^{+}$ATPase.

Studies with knockout mice have shown the physiological importance of transporters for proper synaptic function (Giros et al. 1996; Rothstein et al. 1996; Bengel et al. 1998; Gomeza et al. 2003a,b; Murphy and Lesch 2008). In addition to the expected reductions in transmitter clearance, these models have revealed a profound contribution of transporters to presynaptic neurotransmitter homeostasis, with significantly reduced pools (particularly for DA, NE, and 5-HT) in the absence of reuptake (Fig. 1). Profound changes in pre- and postsynaptic receptors also occur in these models, underscoring the functional significance of transporters for both sides of the synapse.

Pharmacology of Plasma Membrane Neurotransmitter Transport

Pharmacology has played a crucial role in the study of neurotransmitter transporters. In the late 1950s and early 1960s, the availability of 
highly sensitive fluorescence and radiotracer flux assays for epinephrine, norepinephrine (NE), DA and 5-HT enabled Julius Axelrod and his colleagues to identify reuptake as the major mechanism that terminates synaptic transmission (Axelrod 2003). In particular, the group showed that the actions of multiple psychotropic drugs, including cocaine and tricyclic antidepressants, derive from their inhibition of biogenic amine reuptake (Whitby et al. 1960; Axelrod 1961; Hertting et al. 1961; Glowinski and Axelrod 1964). Two decades later, scientists at Eli Lilly would use the same assay to identify the blockbuster, 5-HT-selective reuptake inhibitor (SSRI), fluoxetine (Prozac ${ }^{\mathrm{TM}}$ ) (Fuller and Wong, 1990). More recently, antagonists that target the norepinephrine transporter (NET) and dopamine transporter (DAT) more selectively (e.g., the NET inhibitor atomoxetine or the DAT inhibitor methylphenidate) have found clinical uses in the treatment of attention-deficit hyperactivity disorder (ADHD). It has also become clear that OCT-3, a transporter that confers low-affinity but high-capacity uptake, contributes to 5-HT clearance (Daws et al. 2006; Baganz et al. 2008). OCT-3 is highly expressed in midbrain raphe nuclei (see Allen Brain Atlas at http://www.brain-map.org/), but its presynaptic role remains unknown. Indeed, the contribution of OCT-3 to 5-HT clearance is most evident in cases of SERT deficiency (Baganz et al. 2008). In addition, GABA transporter subtypes continue to receive attention for the treatment of epilepsy (Madsen et al. 2010), and transporters for glycine (a coagonist with glutamate at NMDA receptors) for the treatment of schizophrenia (Hashimoto 2010). EAATs have been the target of far less drug discovery, no doubt reflecting the concern over excessive elevation of extracellular glutamate, which can be excitotoxic. Potentiation of EAAT activity remains an interesting, but largely unexplored area of neurotransmitter transporter pharmacology.

Cocaine and D-amphetamine (AMPH), two highly addictive psychostimulants, interact with DAT, NET, and SERT proteins rather nonselectively and rapidly elevate synaptic levels of their corresponding biogenic amine substrates, although through distinct mechanisms. Cocaine is a competitive transporter inhibitor (Carroll et al. 1997), whereas AMPH and its congeners are competitive substrates, again acting on all three biogenic amine transporters. By competing with the uptake of DA, AMPH would be expected to increase extracellular biogenic amine. However, the mechanisms by which AMPH raises synaptic neurotransmitter are far more complex (Blakely et al. 2005). First, external amphetamine can exchange with cytosolic monoamine, then diffuse back out of the cell for repeated rounds of exchange and hence cause the efflux of monoamine. AMPH can also elevate cytosolic monoamine by competing for uptake into vesicles, or by dissipation of the $\mathrm{H}^{+}$electrochemical driving force for vesicle storage (Sulzer et al. 1993). The elevated cytosolic concentrations of DA, NE, and 5-HT can then not only retard uptake, but promote transporter reversal ("efflux") across the plasma membrane. The amphetamine analog methylenedioxymethamphetamine (MDMA, "ecstasy") has a similar effect, but limited to the serotonin transporter SERT (Rudnick and Wall 1992). Interestingly, AMPH produces a rise in intracellular $\mathrm{Ca}^{2+}$ (Gnegy et al. 2004), possibly by reducing the $\mathrm{pH}$ gradients needed to sequester $\mathrm{Ca}^{2+}$. AMPH also leads to serine phosphorylation at the amino terminus of DAT mediated by $\mathrm{Ca}^{2+} /$ calmodulin dependent kinase CaMKII, and phosphorylation at these sites appears to promote a state permissive for efflux (Fog et al. 2006). It is reasonable to wonder whether a mechanism that shifts the susceptibility of the transporters between influx and efflux represents a disturbance in transporter regulation because of a foreign substance, or a process used under physiological conditions. Further studies are needed to understand the physiological and pathophysiological relevance of transportermediated neurotransmitter efflux.

Early electrophysiological studies of heterologously expressed NET, DAT, and SERT revealed significant neurotransmitter-gated ion flow, which exceeded that needed for coupling to neurotransmitter uptake (Blakely et al. 1994). These observations suggest multiple conductance states for neurotransmitter transporters, one that is stoichiometrically coupled to ion 
movement, and another that resembles the uncoupled flow of ions seen with ligand-gated channels (DeFelice and Blakely 1996; Su et al. 1996). Galli and colleagues detected NE-gated conductances in NET-transfected HEK-293 cells (Galli et al. 1996), and by carbon fiber amperometry identified NE flux states that coincided with channel openings (Galli et al. 1998), suggesting that at least under some circumstances, channel events can support neurotransmitter uptake. But are these findings an artifact of heterologous expression? The cells used lack a number of NET-interacting proteins (e.g., syntaxin $1 \mathrm{~A}, \mathrm{SYN}$ ) that can alter NET activity and NET currents. However, Carvelli and coworkers have also detected neurotransmitter-gated channel states in cultured DA neurons (Carvelli et al. 2004). In addition, DATmediated currents can influence the excitability of mammalian DA neurons (Ingram et al. 2002), which seems unlikely if changes in membrane potential depend on the small amount of ion flow arising from the traditional uptake process. SERT-dependent currents can also be detected in neurons, in which charge flux is developmentally regulated and dependent on the interactions of SERT with SYN (Quick 2003). Remarkably, the coupling stoichiometry predicted from 5-HT uptake studies $\left(1 \mathrm{Na}^{+} / 1 \mathrm{Cl}^{-} / 15-\mathrm{HT}^{+}\right.$inward and $1 \mathrm{~K}^{+}$moving on the reverse cycle) predicts no net currents coupled to 5-HT uptake, indicating that charge movement must be uncoupled from flux. PKC activation with phorbol esters dissociates SYN from GAT, SERT, NET, and DAT, and when unbound, NET can generate channel activity (Sung et al. 2003). Thus, nonstoichiometric charge movement may reflect transporter regulation, enabling transporters to influence neuronal excitability.

\section{Structure of Plasma Membrane Neurotransmitter Transporters}

The cloning of GABA, glycine, NE, DA, and 5-HT transporters showed that these molecules belong to a larger family of $\mathrm{Na}^{+}$and $\mathrm{Cl}^{-}$coupled transporters (SLC6 family) with predicted 12 transmembrane domains (TMDs) and cytosolic amino and carboxyl termini. Shortly after, cloning and sequence analysis of multiple EAAT isoforms showed that these transporters lie within a distinct gene family (SLC1) (Amara 1992) with 8-10 TMDs. Sedimentation and immunoprecipitation studies have supported a homomultimeric structure for both families, but each monomer appears to have the capacity for transport (Horiuchi et al. 2001; Hahn et al. 2003; Torres et al. 2003a; Yernool et al. 2003).

Transporter structure-function studies took a major leap forward with the elucidation of high resolution X-ray crystal structures for bacterial members of the SLC1 and SLC6 families. The first structure of an SLC1 family member, a glutamate transporter from Pyrococcus horikoshii, $(\mathrm{GltP}(\mathrm{Ph}))$ revealed a "bowl-shaped" trimer with a large solvent vestibule and three distinct substrate binding sites, one per monomer (Yernool et al. 2004). The authors suggested that helical hairpins cradling the substrate binding sites serve as gates that control glutamate access to the cytosol (Fig. 2). The structure of the first SLC6 representative, a leucine transporter from Aquifex aeolicus (LeuT), revealed a monomeric structure of 12 TMDs with two groups of helices related to each other via a pseudo two-fold axis of symmetry and a set of helices with inverted topology (TMs 1-5 and 6-10) (Fig. 3) (Yamashita et al. 2005). However, LeuT was crystalized with a single putative substrate bound at a site organized in the plane of the membrane by 4 TMDs ( 1 , 3,5 , and 8 ), in a closed conformation. A potential dimer interface between LeuT monomers was also identified involving TMDs 10 and 11. Since the solution of $\mathrm{GltP}(\mathrm{Ph})$ and LeuT crystal structures, additional structures of other bacterial homologs and related transporters have been obtained in different conformations and with different ligands bound, providing essential information about substrate recognition, ionic coupling (e.g., by $\mathrm{Cl}^{-}$) (Zomot et al. 2007) and conformational changes during the transport cycle, as well as opportunities for homology modeling of the vertebrate neurotransmitter transporters (Andersen et al. 2009; Krishnamurthy et al. 2009; Sinning et al. 2010). Recent single molecule studies have also helped to characterize the movement of internal and external gates predicted by the structures (Zhao et al. 2010). 

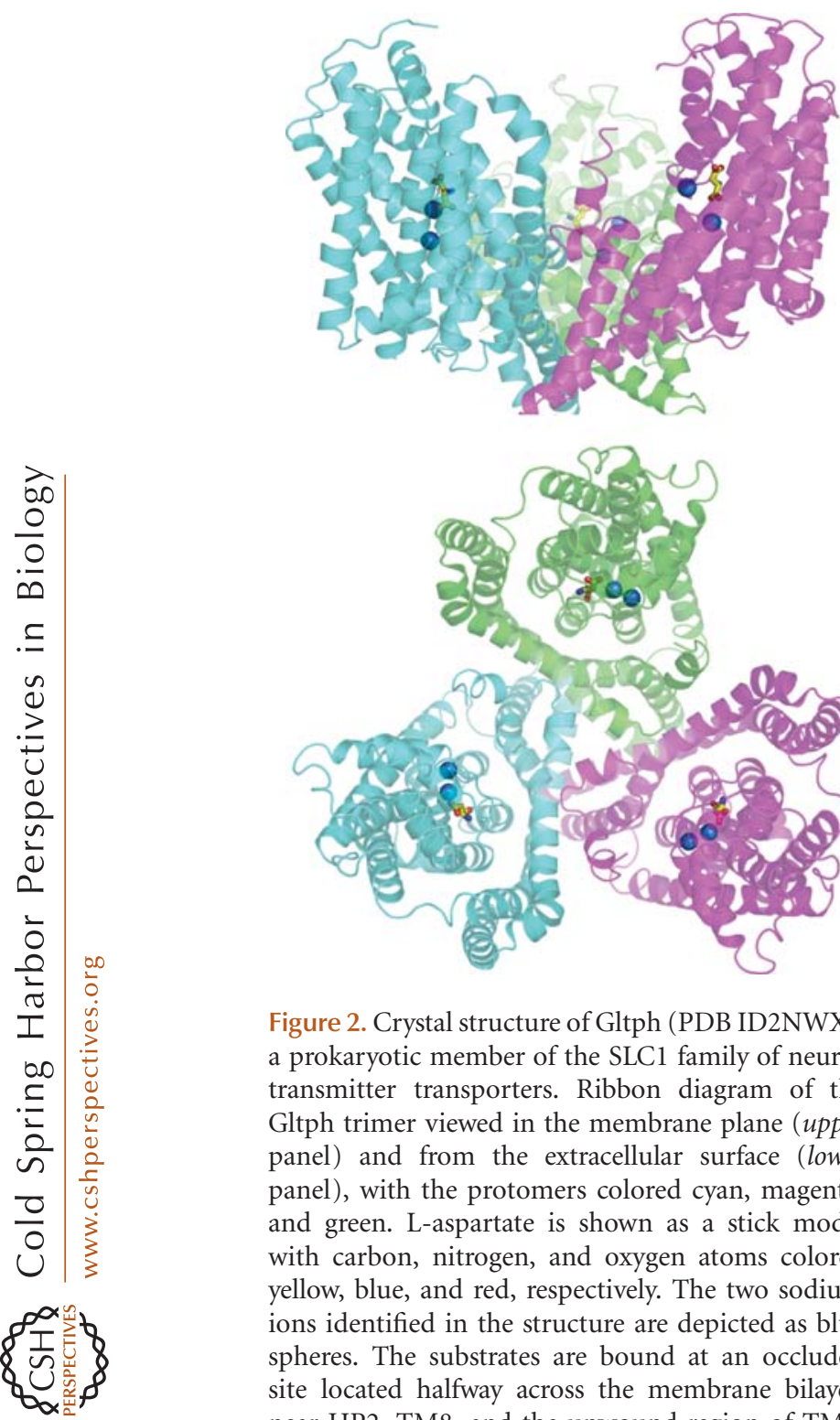

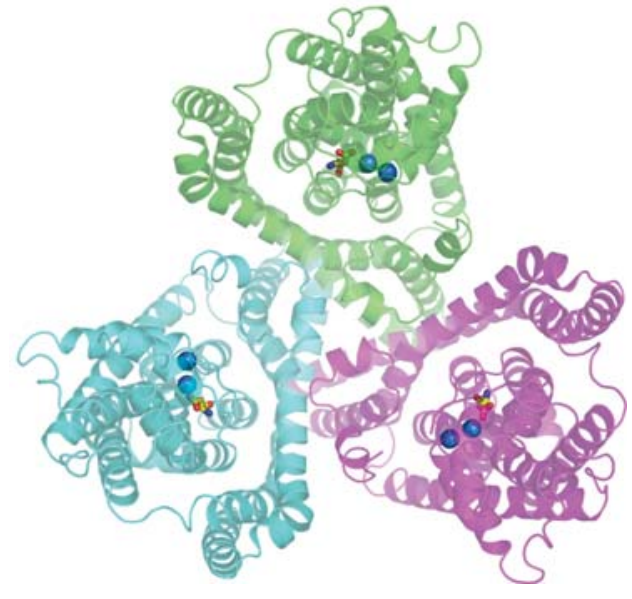

Figure 2. Crystal structure of Gltph (PDB ID2NWX), a prokaryotic member of the SLC1 family of neurotransmitter transporters. Ribbon diagram of the Gltph trimer viewed in the membrane plane (upper panel) and from the extracellular surface (lower panel), with the protomers colored cyan, magenta, and green. L-aspartate is shown as a stick model with carbon, nitrogen, and oxygen atoms colored yellow, blue, and red, respectively. The two sodium ions identified in the structure are depicted as blue spheres. The substrates are bound at an occluded site located halfway across the membrane bilayer, near HP2, TM8, and the unwound region of TM7. (Figure courtesy of Dr. Satinder K. Singh, Department of Cellular and Molecular Physiology, Yale University School of Medicine.)

Regulation of Neurotransmitter Transporters: Transcription

Regulation of neurotransmitter transporters by transcription and splicing remains much less well understood than posttranscriptional mechanisms. The most highly studied transcriptional regulatory sequence for a neurotransmitter transporter is a repeat in the SERT promoter, termed the 5HTTLPR (Lesch et al. 1996). Fewer repeats, in the so-called short ( $s$ ) forms of the promoter, appear to reduce mRNA and protein expression relative to promoters with a greater number of repeats, (the long (1) promoter variant). In humans, the (s) variant has been associated with neuroticism and anxiety traits (Lesch et al. 1996), and in some studies, with aspects of mood disorders (Kim et al. 2000; Pollock et al. 2000), particularly the response to adverse events (Caspi et al. 2003) and antidepressants (Zalsman et al. 2006). Although much remains to be learned regarding the transcriptional regulation of both SLC1 and SLC6 family members, small molecule modulators of transporter gene expression can be identified even in the absence of detailed mechanistic information. For example, Rothstein and workers (2005) identified molecules related to $\beta$-lactam antibiotics that enhance expression of the EAAT2/ GLT1 gene, thereby conferring neuroprotection in cultured cells and animal models.

Regulation of Neurotransmitter Transporters: Trafficking and Phosphorylation

Like all membrane proteins involved in cell signaling, neurotransmitter transporters are known to undergo both constitutive and regulated trafficking to and from the cell surface, a process influenced by multiple protein kinases (Ramamoorthy et al. 2011). In addition, neurotransmitter transporters have been found to undergo phosphorylation-dependent catalytic activation (Steiner et al. 2008).

Only a few phosphorylation sites in neurotransmitter transporters have been carefully identified and the importance of none have been established in vivo. PKC can phosphorylate glutamate transporter GLT1/EAAT2 (Casado et al. 1993), and activation of PKC reduces surface expression of GLT-1 (Kalandadze et al. 2002), but the relationship between phosphorylation and trafficking remains unclear. On the other hand, PKC activation results in the phosphorylation of EAAT3 at Ser465, and this event correlates with enhanced activity and plasma 


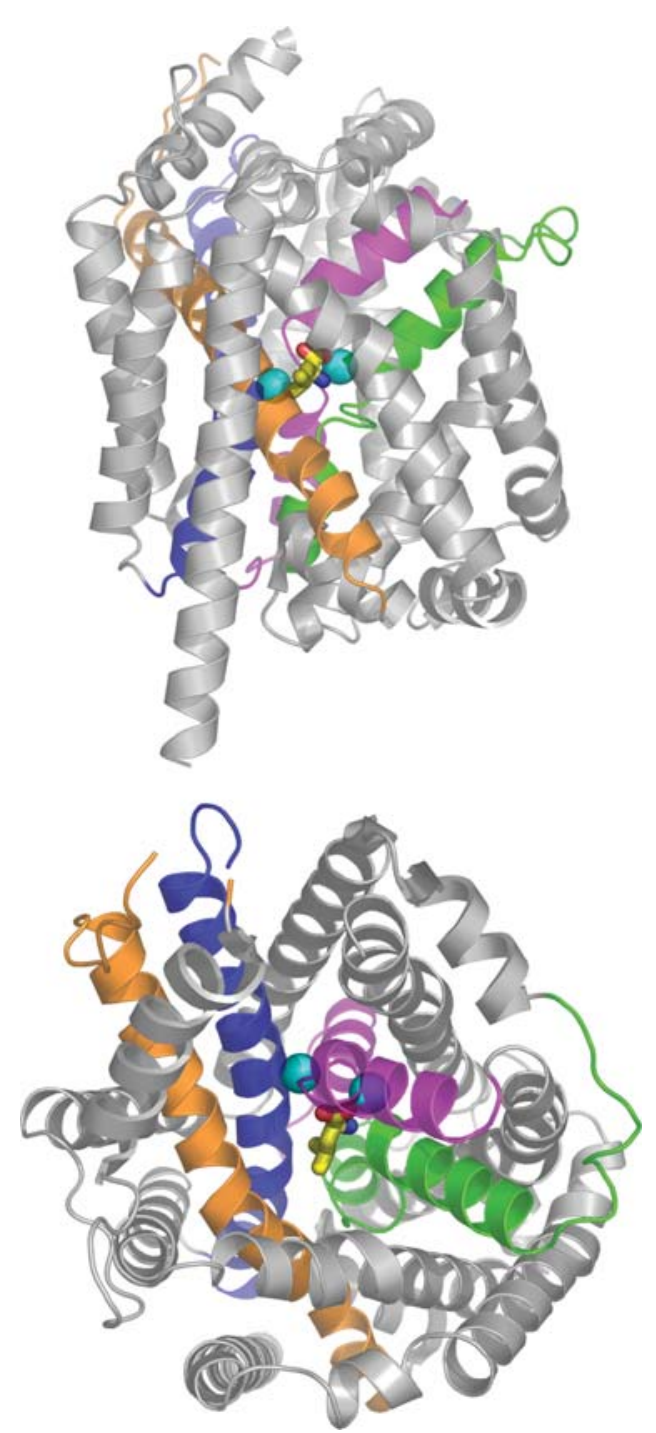

Figure 3. Crystal structure of LeuT (PDB ID 2A65), a prokaryotic member of the SLC6 family of neurotransmitter transporters. Ribbon diagram of LeuT viewed in the plane of the membrane (upper panel) and from the extracellular surface (lower panel). TMs $1,3,6,8$ are colored magenta, orange, green, and blue, respectively. L-leucine is shown as a stick model with carbon, nitrogen, and oxygen atoms colored yellow, blue, and red, respectively. The two sodium ions are depicted as cyan spheres. The substrates are bound at an occluded site at the center of the membrane bilayer, near TMs 3 and 8 and the unwound sections of TMs 1 and 6. (Figure courtesy of Dr. Satinder K. Singh, Department of Cellular and Molecular Physiology, Yale University School of Medicine.)
Vesicular and Plasma Membrane Transporters

membrane trafficking (Baik et al. 2009). In the case of the SLC6 family, PKC activation both phosphorylates and down-regulates DAT (Vaughan et al. 1997), but the phosphorylation does not appear important for trafficking, implicating the phosphorylation of other proteins in the effects on trafficking of DAT (Granas et al. 2003). By contrast, the phosphorylation of Nterminal serines by CaMKII and PKC promotes efflux, such as that triggered by AMPH (Foster et al. 2002; Fog et al. 2006). DAT also undergoes phosphorylation by MAPK in vitro and in vivo (Gorentla et al. 2009), and recent studies of D2 DA receptor modulation of DAT trafficking have been linked to ERK activation (Bolan et al. 2007).

SERT also undergoes phosphorylation by a range of kinases (Blakely et al. 1998; Ramamoorthy et al. 1998; Samuvel et al. 2005). Interestingly, phosphorylation and endocytosis of SERT by PKC can be suppressed by 5-HT (Ramamoorthy and Blakely 1999), suggesting a mechanism for the transmitter to regulate its own clearance. PKG activatioin also stimulates SERT trafficking and activity (Zhu et al. 2004, 2005; Ramamoorthy et al. 2007; Steiner et al. 2008).

\section{Neurotransmitter Transporter-Associated Proteins}

Previous work has identified three major classes of protein interactions made by plasma membrane neurotransmitter transporters: with SNARE proteins, in particular syntaxin 1A (SYN1A), with kinases and phosphatases, including PKC, PKG, CaMKII, and protein phosphatase 2A (PP2A); and with cell surface receptors (e.g., D2 DA receptors and integrin $\beta 3$-containing adhesion receptors (ITGB3)).

PKC increases cell surface expression of the GABA transporter GAT1 when the transporter is expressed in Xenopus oocytes along with brain mRNA, suggesting a role for other proteins (Quick et al. 1997). Indeed, coexpression of the SNARE protein SYN1A reproduced the effect of brain mRNA. Subsequent work has revealed that GAT1 and SYN1A associate directly in a higher order complex, and this complex can be regulated by PKC activation (Beckman et al. 1998). In cultured hippocampal neurons, SYN1A 
inhibits GAT1 activity and clostridial toxins reverse this effect (Deken et al. 2000), consistent with a role for SYN1A interactions in regulation of GAT1 trafficking.

Interactions with SYN1A have since been described for many neurotransmitter transporters, and show three main features. First, intracellular calcium inhibits SYN1A/NET association, and SYN1A/NET interactions inhibit both NE uptake and associated currents in detached patches (Sung et al. 2003). A rise in intracellular $\mathrm{Ca}^{2+}$ that promotes vesicular fusion is thus predicted to cause dissociation of SYN1A from NET, increasing NE transport activity to clear transmitter released at the same time. Second, although SYN1A can suppress entry of $\mathrm{DA} / \mathrm{NE}$ and inward channel states, it may also promote the outward movement of DA through both coupled and uncoupled pathways. (Binda et al. 2008). Indeed, AMPH itself stimulates DAT/SYN association, mediated by the first 33 amino acids of the DAT amino terminus and by CaMKII activation (Fog et al. 2006).

Third, presynaptic DAT/SYN interactions have now been shown to regulate DA signaling in vivo. Like its mammalian counterparts, C. elegans DAT (DAT-1) interacts with the SYN1A ortholog UNC-64 (Carvelli et al. 2008) and disrupting this interaction leads to excessive channel activity and tonic depolarization. DA uptake appears normal and the animals show a phenotype characteristic of excessive DA release (McDonald et al. 2007). If SYN cannot interact normally with DAT-1, the transporter may thus enter into a state that depolarizes DA terminals and produces increased DA release.

Neurotransmitter transporters can form stable associations with protein phosphatases and kinases that enable the rapid, local modulation of transporter trafficking and function. In one example, SERT associates with the catalytic subunit of Ser/Thr phosphatase PP2Ac (Bauman et al. 2000), with similar association observed for NET and DAT. Interestingly, the transport of 5-HT attenuates the phosphorylation and endocytosis of SERT triggered by phorbol esters (Ramamoorthy and Blakely 1999), and this might reflect either reduced association of PKC (or a PKC-regulated SERT kinase) or enhanced dephosphorylation. The carboxyl terminus of DAT also harbors a PDZ recognition sequence that interacts with PICK1, a PDZ domain protein implicated in DAT trafficking (Torres et al. 2001).

Do the receptors that functionally modulate transporter signaling also physically associate with transporters? D2 DA receptors have been found to associate with DAT (Lee et al. 2007); the interaction appears to be agonist-independent and results in enhanced transporter surface expression and DA uptake. A3 adenosine receptors (A3ARs) may associate with SERT (Zhu et al. submitted). Activation of A3ARs rapidly increases endogenous SERT function (Zhu et al. 2004, 2007), through a mechanism involving PKG1 and p38 MAPK effects on SERT trafficking and catalytic activity. In contrast to D2 DA receptor interactions with DAT, A3AR agonist enhances the association of SERT with A3AR and surface expression of SERT. NOS, the enzyme that produces cGMP to activate PKG1 and SERT (Zhu et al. 2004), also appears to associate physically with SERT in vivo (Chanrion et al. 2007). Thus, multiple components of a signaling system that links adenosine receptor modulation to 5-HT clearance appear to form a complex.

Human Diseases Linked to Plasma Membrane Neurotransporter Dysfunction

The first reported human disease produced by mutation in a neurotransmitter transporter is the Ala457Pro substitution in NET, found in two sisters with orthostatic intolerance (OI), also known as POTS for postural orthostatic tachycardia syndrome) (Shannon et al. 2000). OI produces syncope on standing, and is associated with elevated plasma NE and DHPG/NE ratios. Genetically, the NET Ala457Pro mutation appears to be the major determinant of the OI phenotype in this family, and studies in vitro show that the Ala457Pro NET variant shows greatly reduced surface expression and a consequent, dramatic reduction in NE uptake (Hahn et al. 2003). Moreover, the mutant shows a dominant negative effect on wild type NET, trapping the wild type protein inside the cell. 
Although the Ala457Pro mutation is rare, loss of NE clearance and/or NET has been observed in OI subjects more broadly, suggesting that other mechanisms can produce the syndrome (Jacob et al. 1997; Lambert et al. 2008). Interestingly, OI subjects also show cognitive impairments that may reflect NET activity and NE signaling in the brain (Raj et al. 2009). Supporting this possibility, a promoter variant in NET has been found to recruit a transcriptional repressor, leading to reduced NET expression, and influencing risk of ADHD (Kim et al. 2006) as well as systolic blood pressure in healthy subjects (Kohli et al. 2011). A loss-offunction variant in EAAT1-also a putative dominant negative- - has been found in a patient with episodic ataxia, seizures, migraine, and alternating hemiplegia (Jen et al. 2005).

Genetic variation in SERT has been reported to contribute to obsessive-compulsive (OCD) and autism spectrum disorders (ASD). A rare coding variant of SERT (Ile425Val) (Glatt et al. 2001; Ozaki et al. 2003) is enriched in subjects with OCD, Asperger's syndrome, anorexia and major depression in two unrelated families. In vitro studies subsequently showed that the Ile425Val variant confers elevated SERT activity attributable to catalytic activation (Kilic et al. 2003; Prasad et al. 2005). Five additional SERT variants were then also identified in ASD, and all confer a gain of function (Sutcliffe et al. 2005; Prasad et al. 2009). One of the SERT variants-Gly56Ala-is hyperphosphorylated and occupies a high-affinity, hyperactive state that occludes further stimulation by PKG and P38 MAPK (Prasad et al. 2005). In contrast, the other hyperactive SERT variants identified by Sutcliffe et al. show increased cell surface expression.

Because drugs that act on DAT-methylphenidate (Ritalin ${ }^{\mathrm{TM}}$ ) and AMPH (Adderall ${ }^{\mathrm{TM}}$ ) can be effective for treatment of ADHD, a cohort of ADHD subjects was screened for DAT mutations, identifying the Ala559Val DAT variant (Mazei-Robison and Blakely 2005). Functional studies of Ala559Val DAT initially failed to detect changes in inward DA flux or DAT surface expression, but when the cells were loaded with DA, amperometric recordings revealed spontaneous efflux of DA that was enhanced by depolariza- tion (Mazei-Robison et al. 2008). Remarkably, AMPH no longer caused DA efflux but, rather, antagonized the outward movement of DA. Further, the phenotype of the Ala559Val variant depended on D2 DA receptor stimulation, CaMKII activity and amino-terminal phosphorylation sites, very similar to the effects of AMPH (Bowton et al. 2010). Drugs targeting DAT thus interact differently with altered transport proteins, whether incurred by mutation or by regulation. Although this DAT variant was not observed in hundreds of controls, it was reported in a girl with bipolar disorder (Grunhage et al. 2000). The comorbidity of ADHD and bipolar disorder (Klassen et al.2010) suggests that the variant may affect more general behavioral traits that underlie multiple DA-linked disorders.

\section{CONCLUSION}

Recent work has shown that although originally identified as the targets of psychoactive drugs, neurotransmitter transporters have a crucial role in synaptic transmission. They also undergo regulation at the level of catalytic activity and trafficking in response to physiological as well as pharmacological stimuli. As a result, neurotransmitter transporters contribute not only to the acute effect of drugs, but to the longterm adaptation that underlies normal physiology as well as drug addiction and other neuropsychiatric disease. However, we still understand relatively little about the fundamental properties of many neurotransmitter transporters, such as their associated ionic conductances. Future work thus still needs to elucidate their basic function as well as the structural basis for transport, the mechanisms of regulation, and their physiological role in neural systems and in behavior.

\section{REFERENCES}

Accardi A, Miller C. 2004. Secondary active transport mediated by a prokaryotic homologue of $\mathrm{ClC} \mathrm{Cl-channels.}$ Nature 427: 803-807.

Ahnert-Hilger G, Nurnberg B, Exner T, Schafer T, Jahn R. 1998. The heterotrimeric $\mathrm{G}$ protein $\mathrm{G} 02$ regulates catecholamine uptake by secretory vesicles. EMBO J 17: 406-413. 
Aihara Y, Mashima H, Onda H, Hisano S, Kasuya H, Hori T, Yamada S, Tomura H, Yamada Y, Inoue I, et al. 2000. Molecular cloning of a novel brain-type $\mathrm{Na}^{+}$-dependent inorganic phosphate cotransporter. J Neurochem 74: $2622-2625$.

Albrecht J, Sonnewald U, Waagepetersen HS, Schousboe A. 2007. Glutamine in the central nervous system: Function and dysfunction. Front Biosci 12: 332-343.

Alfonso A, Grundahl K, Duerr JS, Han H-P, Rand JB. 1993. The Caenorhabditis elegans unc-17 gene: A putative vesicular acetylcholine transporter. Science 261: 617-619.

Amara SG. 1992. A tale of two families. Nature 360: 420421.

Amilhon B, Lepicard E, Renoir T, Mongeau R, Popa D, Poirel O, Miot S, Gras C, Gardier AM, Gallego J, et al. 2010. VGLUT3 (vesicular glutamate transporter type 3) contribution to the regulation of serotonergic transmission and anxiety. J Neurosci 30: 2198-2210.

Andersen J, Taboureau O, Hansen KB, Olsen L, Egebjerg J, Stromgaard K, Kristensen AS. 2009. Location of the antidepressant binding site in the serotonin transporter: Importance of Ser-438 in recognition of citalopram and tricyclic antidepressants. J Biol Chem 284: 10276-10284.

Armano S, Coco S, Bacci A, Pravettoni E, Schenk U, Verderio C, Varoqui H, Erickson JD, Matteoli M. 2002. Localization and functional relevance of system a neutral amino acid transporters in cultured hippocampal neurons. I Biol Chem 277: 10467-10473.

Asada H, Kawamura Y, Maruyama K, Kume H, Ding RG, Kanbara N, Kuzume H, Sanbo M, Yagi T, Obata K. 1997. Cleft palate and decreased brain $\gamma$-aminobutyric acid in mice lacking the $67-\mathrm{kDa}$ isoform of glutamic acid decarboxylase. Proc Natl Acad Sci 94: 6496-6499.

Atlante A, Passarella S, Pierro P, Di Martino C, Auagliariello E. 1996. The mechanism of proline/glutamate antiport in rat kidney mitochondria: Energy dependence and glutamate-carrier involvement. Eur J Biochemist 241: 171177.

Axelrod J. 1971. Noradrenaline: Fate and control of its biosynthesis. Science 173: 598-606.

Axelrod J. 2003. Journey of a late blooming biochemical neuroscientist. J Biol Chem 278: 1-13.

Axelrod J, Whitby L, Hertting G. 1961. Effect of psychotropic drugs on the uptake of $3 \mathrm{H}$-norepinephrine by tissues. Science 133: 383-384.

Baganz NL, Horton RE, Calderon AS, Owens WA, Munn JL, Watts LT, Koldzic-Zivanovic N, Jeske NA, Koek W, Toney GM, et al. 2008. Organic cation transporter 3: Keeping the brake on extracellular serotonin in serotonin-transporter-deficient mice. Proc Natl Acad Sci 105: 1897618981.

Baik HJ, Huang Y, Washington JM, Zuo Z. 2009. Critical role of s465 in protein kinase C-increased rat glutamate transporter type 3 activity. Int J Neurosci 119: 1419-1428.

Bankston LA, Guidotti G. 1996. Characterization of ATP transport into chromaffin granule ghosts. Synergy of ATP and serotonin accumulation in chromaffin granule ghosts. J Biol Chem 271: 17132-17138.

Bauman AL, Apparsundaram S, Ramamoorthy S, Wadzinski BE, Vaughan RA, Blakely RD. 2000. Cocaine and antidepressant-sensitive biogenic amine transporters exist in regulated complexes with protein phosphatase $2 \mathrm{~A}$. J Neurosci 20: $7571-7578$.

Bayer MJ, Reese C, Buhler S, Peters C, Mayer A. 2003. Vacuole membrane fusion: V0 functions after trans-SNARE pairing and is coupled to the $\mathrm{Ca}^{2+}$-releasing channel. J Cell Biol 162: 211-222.

Beckman ML, Bernstein EM, Quick MW. 1998. Protein kinase $C$ regulates the interaction between a GABA transporter and syntaxin 1A. J Neurosci 18: 6103-6112.

Beckstead MJ, Grandy DK, Wickman K, Williams JT. 2004. Vesicular dopamine release elicits an inhibitory postsynaptic current in midbrain dopamine neurons. Neuron 42: 939-946.

Bellocchio EE, Reimer RJ, Fremeau RT Jr, Edwards RH. 2000. Uptake of glutamate into synaptic vesicles by an inorganic phosphate transporter [see comments]. Science 289: $957-960$.

Bengel D, Murphy DL, Andrews AM, Wichems CH, Feltner D, Heils A, Mossner R, Westphal H, Lesch KP. 1998. Altered brain serotonin homeostasis and locomotor insensitivity to 3,4-methylenedioxymetamphetamine ("ecstasy") in serotonin transporter-deficient mice. $\mathrm{Mol}$ Pharmacol 53: 649-655.

Bergles DE, Diamond JS, Jahr CE. 1999. Clearance of glutamate inside the synapse and beyond. Curr Opin Neurobiol 9: $293-298$

Bergquist F, Niazi HS, Nissbrandt H. 2002. Evidence for different exocytosis pathways in dendritic and terminal dopamine release in vivo. Brain Res 950: 245-253.

Binda F, Dipace C, Bowton E, Robertson SD, Lute BJ, Fog JU, Zhang M, Sen N, Colbran RJ, Gnegy ME, et al. 2008. Syntaxin 1A interaction with the dopamine transporter promotes amphetamine-induced dopamine efflux. Mol Pharmacol 74: 1101-1108.

Birgner C, Nordenankar K, Lundblad M, Mendez JA, Smith C, le Greves M, Galter D, Olson L, Fredriksson A, Trudeau LE, et al. 2010. VGLUT2 in dopamine neurons is required for psychostimulant-induced behavioral activation. Proc Natl Acad Sci 107: 389-394.

Blakely RD, DeFelice LJ, Hartzell HC. 1994. Molecular physiology of norepinephrine and serotonin transporters. $J$ Exp Biol 196: 263-281.

Blakely RD, Ramamoorthy S, Schroeter S, Qian Y, Apparsundaram S, Galli A, DeFelice LJ. 1998. Regulated phosphorylation and trafficking of antidepressant-sensitive serotonin transporter proteins. Biol Psychiatry 44: 169-178.

Blakely RD, DeFelice LJ, Galli A. 2005. Biogenic amine neurotransmitter transporters: Just when you thought you knew them. Physiology (Bethesda) 20: 225-231.

Bolan EA, Kivell B, Jaligam V, Oz M, Jayanthi LD, Han Y, Sen N, Urizar E, Gomes I, Devi LA, et al. 2007. D2 receptors regulate dopamine transporter function via an extracellular signal-regulated kinases 1 and 2-dependent and phosphoinositide 3 kinase-independent mechanism. Mol Pharmacol 71: 1222-1232.

Born GV, Gillson RE. 1957. The uptake of 5-hydroxytryptamine by blood platelets. J Physiol 137: 82-83.

Boulland JL, Qureshi T, Seal RP, Rafiki A, Gundersen V, Bergersen LH, Fremeau RT Jr, Edwards RH, StormMathisen J, Chaudhry FA. 2004. Expression of the vesicular 
glutamate transporters during development indicates the widespread corelease of multiple neurotransmitters. $J$ Comp Neurol 480: 264-280.

Bowton E, Saunders C, Erreger K, Sakrikar D, Matthies HJ, Sen N, Jessen T, Colbran RJ, Caron MG, Javitch JA, et al. 2010. Dysregulation of dopamine transporters via dopamine D2 autoreceptors triggers anomalous dopamine efflux associated with attention-deficit hyperactivity disorder. J Neurosci 30: 6048-6057.

Broer A, Albers A, Setiawan I, Edwards RH, Chaudhry FA, Lang F, Wagner CA, Broer S. 2002. Regulation of the glutamine transporter $\mathrm{SN} 1$ by extracellular $\mathrm{pH}$ and intracellular sodium ions. J Physiol 539: 3-14.

Brunk I, Blex C, Rachakonda S, Holtje M, Winter S, Pahner I, Walther DJ, Ahnert-Hilger G. 2006. The first luminal domain of vesicular monoamine transporters mediates G-protein-dependent regulation of transmitter uptake. J Biol Chem 281: 33373-33385.

Busch AE, Schuster A, Waldegger S, Wagner CA, Zempel G, Broer S, Biber J, Murer H, Lang F. 1996. Expression of a renal type I sodium/phosphate transporter ( $\mathrm{NaPi}-1)$ induces a conductance in Xenopus oocytes permeable for organic and inorganic anions. Proc Natl Acad Sci 93: 5347-5351.

Carlsson A, Hillarp NA, Waldeck B. 1963. Analysis of the $\mathrm{Mg}^{2+}$-ATP dependent storage mechanism in the amine granules of the adrenal medulla. Acta Physiol Scand 264: 7369-7376.

Carneiro AM, Cook EH, Murphy DL, Blakely RD. 2008. Interactions between integrin $\alpha \operatorname{IIb} \beta 3$ and the serotonin transporter regulate serotonin transport and platelet aggregation in mice and humans. J Clin Invest 118: $1544-1552$.

Carroll FI, Lewin AH, Kuhar MJ. 1997. Dopamine transporter uptake blockers: Structure-activity relationships. In Neurotransmitter transporters: Structure, function, and regulation (ed. Reith MEA), pp. 263-296. Humana Press, Totowa, NJ.

Carvelli L, McDonald PW, Blakely RD, DeFelice LJ. 2004. Dopamine transporters depolarize neurons by a channel mechanism. Proc Natl Acad Sci 101: 16046-16051.

Carvelli L, Blakely RD, DeFelice LK. 2008. Dopamine transporter/syntaxin 1A interactions regulate transporter channel activity and dopaminergic synaptic transmission. Proc Natl Acad Sci 105: 14192-14197.

Casado M, Bendahan A, Zafra F, Danbolt NC, Aragon C, Gimenez C, Kanner BI. 1993. Phosphorylation and modulation of brain glutamate transporters by protein kinase C. J Biol Chem 268: 27313-27317.

Caspi A, Sugden K, Moffitt TE, Taylor A, Craig IW, Harrington H, McClay J, Mill J, Martin J, Braithwaite A, et al. 2003. Influence of life stress on depression: Moderation by a polymorphism in the 5-HTT gene. Science 301: 386-389.

Caudle WM, Richardson JR, Wang MZ, Taylor TN, Guillot TS, McCormack AL, Colebrooke RE, Di Monte DA, Emson PC, Miller GW. 2007. Reduced vesicular storage of dopamine causes progressive nigrostriatal neurodegeneration. J Neurosci 27: 8138-8148.

Cervini R, Houhou L, Pradat PF, Bejanin S, Mallet J, Berrard S. 1995. Specific vesicular acetylcholine transporter pro- moters lie within the first intron of the rat choline acetyltransferase gene. J Biol Chem 270: 24654-24657.

Chanrion B, Mannoury la Cour C, Bertaso F, Lerner-Natoli M, Freissmuth M, Millan MJ, Bockaert J, Marin P. 2007. Physical interaction between the serotonin transporter and neuronal nitric oxide synthase underlies reciprocal modulation of their activity. Proc Natl Acad Sci 104: 8119-8124.

Chaudhry FA, Reimer RJ, Krizaj D, Barber D, StormMathisen J, Copenhagen DR, Edwards RH. 1999. Molecular analysis of system $\mathrm{N}$ suggests novel physiological roles in nitrogen metabolism and synaptic transmission. Cell 99: 769-780.

Chaudhry FA, Reimer RJ, Edwards RH. 2002. The glutamine commute: Take the N line and transfer to the A.J Cell Biol 157: 349-355.

Christgau S, Aanstoot HJ, Schierbeck H, Begley K, Tullin S, Hejnaes K, Baekkeskov S. 1992. Membrane anchoring of the autoantigen GAD65 to microvesicles in pancreatic $\beta$ cells by palmitoylation in the NH2-terminal domain. J Cell Biol 118: 309-320.

Chuhma N, Zhang H, Masson J, Zhuang X, Sulzer D, Hen R, Rayport S. 2004. Dopamine neurons mediate a fast excitatory signal via their glutamatergic synapses. J Neurosci 24: 972-981.

Claxton DP, Quick M, Shi L, de Carvalho FD, Weinstein H, Javitch JA, McHaourab HS. 2010. Ion/substrate-dependent conformational dynamics of a bacterial homolog of neurotransmitter: Sodium symporters. Nat Struct Mol Biol 17: 822-829.

Clements JD. 1996. Transmitter timecourse in the synaptic cleft: Its role in central synaptic function. Trends Neurosci 19: $163-171$.

Cohen SM, Nadler JV. 1997a. Proline-induced inhibition of glutamate release in hippocampal area CA1. Brain Res 769: 333-339.

Cohen SM, Nadler JV. 1997b. Proline-induced potentiation of glutamate transmission. Brain Res 761: 271-282.

Condie BG, Bain G, Gottlieb DI, Capecchi MR. 1997. Cleft palate in mice with a targeted mutation in the $\gamma$-aminobutyric acid-producing enzyme glutamic acid decarboxylase 67. Proc Natl Acad Sci 94: 11451-11455.

Crump FT, Fremeau RT, Craig AM. 1999. Localization of the brain-specific high-affinity L-proline transporter in cultured hippocampal neurons: Molecular heterogeneity of synaptic terminals. Mol Cell Neurosci 13: 25-39.

Curthoys NP, Watford M. 1995. Regulation of glutaminase activity and glutamine metabolism. Annu Rev Nutr 15: 133-159.

Daniels RW, Collins CA, Chen K, Gelfand MV, Featherstone DE, Diantonio A. 2006. A single vesicular glutamate transporter is sufficient to fill a synaptic vesicle. Neuron 49: $11-16$.

Daws LC, Montanez S, Munn JL, Owens WA, Baganz NL, Boyce-Rustay JM, Millstein RA, Wiedholz LM, Murphy DL, Holmes A. 2006. Ethanol inhibits clearance of brain serotonin by a serotonin transporter-independent mechanism. J Neurosci 26: 6431-6438.

DeFelice LJ, Blakely RD. 1996. Pore models for transporters? Biophys J 70: 579-580. 
R.D. Blakely and R.H. Edwards

De Gois S, Schafer MK, Defamie N, Chen C, Ricci A, Weihe E, Varoqui H, Erickson JD. 2005. Homeostatic scaling of vesicular glutamate and GABA transporter expression in rat neocortical circuits. J Neurosci 25: 7121-7133.

Deken SL, Beckman ML, Boos L, Quick MW. 2000. Transport rates of GABA transporters: Regulation by the $\mathrm{N}$-terminal domain and syntaxin 1A. Nat Neurosci 3: 998-1003.

Dobransky T, Rylett RJ. 2005. A model for dynamic regulation of choline acetyltransferase by phosphorylation. J Neurochem 95: 305-313.

Duerr JS, Frisby DL, Gaskin J, Duke A, Asermely K, Huddleston D, Eiden LE, Rand JB. 1999. The cat-1 gene of Caenorhabditis elegans encodes a vesicular monoamine transporter required for specific monoamine-dependent behaviors. J Neurosci 19: 72-84.

Erickson JD, Eiden LE, Hoffman BJ. 1992. Expression cloning of a reserpine-sensitive vesicular monoamine transporter. Proc Natl Acad Sci 89: 10993-10997.

Erickson JD, Varoqui H, Schafer MD, Modi W, Diebler MF Weihe E, Rand J, Eiden LE, Bonner TI, Usdin TB. 1994. Functional identification of a vesicular acetylcholine transporter and its expression from a "cholinergic" gene locus. J Biol Chem 269: 21929-21932.

Erickson JD, Schafer MK-H, Bonner TI, Eiden LE, Weihe E. 1996. Distinct pharmacological properties and distribution in neurons and endocrine cells of two isoforms of the human vesicular monoamine transporter. Proc Natl Acad Sci 93: 5166-5171.

Falkenburger BH, Barstow KL, Mintz IM. 2001. Dendrodendritic inhibition through reversal of dopamine transport. Science 293: 2465-2470.

Farnsworth SJ, Volz TJ, Hanson GR, Fleckenstein AE. 2009. Cocaine alters vesicular dopamine sequestration and potassium-stimulated dopamine release: The role of D2 receptor activation. J Pharmacol Exp Ther 328: 807-812.

Ferguson SM, Savchenko V, Apparsundaram S, Zwick M, Wright J, Heilman CJ, Yi H, Levey AI, Blakely RD. 2003. Vesicular localization and activity-dependent trafficking of presynaptic choline transporters. J Neurosci 23: 9697-9709.

Ferguson SM, Bazalakova M, Savchenko V, Tapia JC, Wright J, Blakely RD. 2004. Lethal impairment of cholinergic neurotransmission in hemicholinium-3-sensitive choline transporter knockout mice. Proc Natl Acad Sci 101: 8762-8767.

Fleckenstein AE, Hanson GR. 2003. Impact of psychostimulants on vesicular monoamine transporter function. Eur Pharmacol 479: 283-289.

Fog JU, Khoshbouei H, Holy M, Owens WA, Vaegter CB, Sen N, Nikandrova Y, Bowton E, McMahon DG, Colbran RJ, et al. 2006. Calmodulin kinase II interacts with the dopamine transporter $\mathrm{C}$ terminus to regulate amphetamine-induced reverse transport. Neuron 51: 417-429.

Fon EA, Pothos EN, Sun BC, Killeen N, Sulzer D, Edwards RH. 1997. Vesicular transport regulates monoamine storage and release but is not essential for amphetamine action. Neuron 19: 1271-1283.

Forgac M. 2007. Vacuolar ATPases: Rotary proton pumps in physiology and pathophysiology. Nat Rev Mol Cell Biol 8: 917-929.
Fortin GD, Desrosiers CC, Yamaguchi N, Trudeau LE. 2006. Basal somatodendritic dopamine release requires snare proteins. J Neurochem 96: 1740-1749.

Foster JD, Pananusorn B, Vaughan RA. 2002. Dopamine transporters are phosphorylated on N-terminal serines in rat striatum. J Biol Chem 277: 25178-25186.

Fremeau RT Jr, Caron MG, Blakely RD. 1992. Molecular cloning and expression of a high affinity L-proline transporter expressed in putative glutamatergic pathways of rat brain. Neuron 8: 915-926.

Fremeau RT Jr, Burman J, Qureshi T, Tran CH, Proctor J, Johnson J, Zhang H, Sulzer D, Copenhagen DR, StormMathisen J, et al. 2002. The identification of vesicular glutamate transporter 3 suggests novel modes of signaling by glutamate. Proc Natl Acad Sci 99: 14488-14493.

Fremeau RT Jr, Kam K, Qureshi T, Johnson J, Copenhagen DR, Storm-Mathisen J, Chaudhry FA, Nicoll RA, Edwards RH. 2004. Vesicular glutamate transporters 1 and 2 target to functionally distinct synaptic release sites. Science 304: 1815-1819.

Fuller RW, Wong DT. 1990. Serotonin uptake and serotonin uptake inhibition. Ann NY Acad Sci 600: 68-78.

Galli A, Blakely RD, DeFelice LJ. 1996. Norepinephrine transporters have channel modes of conduction. Proc Natl Acad Sci 93: 8671-8676.

Galli A, Blakely RD, DeFelice LJ. 1998. Patch-clamp and amperometric recordings from norepinephrine transporters: Channel activity and voltage-dependent uptake. Proc Natl Acad Sci 95: 13260-13265.

Gillespie DC, Kim G, Kandler K. 2005. Inhibitory synapses in the developing auditory system are glutamatergic. Nat Neurosci 8: 332-338.

Giros B, Jaber M, Jones SR, Wightman RM, Caron MG. 1996. Hyperlocomotion and indifference to cocaine and amphetamine in mice lacking the dopamine transporter. Nature 379: 606-612.

Glatt CE, DeYoung JA, Delgado S, Service SK, Giacomini KM, Edwards RH, Risch N, Freimer NB. 2001. Screening a large reference sample to identify very low frequency sequence variants: Comparisons between two genes. Nat Genet 27: 435-438.

Glowinski J, Axelrod J. 1964. Inhibition of uptake of tritiated-noradrenaline in the intact rat brain by imipramine and structurally related compounds. Nature 204: $1318-1319$.

Gnegy ME, Khoshbouei H, Berg KA, Javitch JA, Clarke WP, Zhang M, Galli A. 2004. Intracellular $\mathrm{Ca}^{2+}$ regulates amphetamine-induced dopamine efflux and currents mediated by the human dopamine transporter. $\mathrm{Mol}$ Pharmacol 66: $137-143$.

Gomeza J, Hulsmann S, Ohno K, Eulenburg V, Szoke K, Richter D, Betz H. 2003a. Inactivation of the glycine transporter 1 gene discloses vital role of glial glycine uptake in glycinergic inhibition. Neuron 40: 785-796.

Gomeza J, Ohno K, Hulsmann S, Armsen W, Eulenburg V, Richter DW, Laube B, Betz H. 2003b. Deletion of the mouse glycine transporter 2 results in a hyperekplexia phenotype and postnatal lethality. Neuron 40: 797-806.

Gonzalez MI, Bannerman PG, Robinson MB. 2003. Phorbol myristate acetate-dependent interaction of protein kinase 
Ca and the neuronal glutamate transporter EAAC1. $J$ Neurosci 23: 5589-5593.

Gorentla BK, Moritz AE, Foster JD, Vaughan RA. 2009. Proline-directed phosphorylation of the dopamine transporter N-terminal domain. Biochemistry 48: 1067 1076.

Granas C, Ferrer J, Loland CJ, Javitch JA, Gether U. 2003. $\mathrm{N}$-terminal truncation of the dopamine transporter abolishes phorbol ester- and substance P receptor-stimulated phosphorylation without impairing transporter internalization. J Biol Chem 278: 4990-5000.

Gras C, Herzog E, Bellenchi GC, Bernard V, Ravassard P, Pohl M, Gasnier B, Giros B, El Mestikawy S. 2002. A third vesicular glutamate transporter expressed by cholinergic and serotoninergic neurons. J Neurosci 22: 5442-5451.

Gras C, Amilhon B, Lepicard EM, Poirel O, Vinatier J, Herbin M, Dumas S, Tzavara ET, Wade MR, Nomikos GG et al. 2008. The vesicular glutamate transporter VGLUT3 synergizes striatal acetylcholine tone. Nat Neurosci 11: 292-300.

Gresch PJ, Sved AF, Zigmond MJ, Finlay JM. 1995. Local influence of endogenous norepinephrine on extracellular dopamine in rat medial prefrontal cortex. J Neurochem 65: $111-116$.

Gronborg M, Pavlos NJ, Brunk I, Chua JJ, MunsterWandowski A, Riedel D, Ahnert-Hilger G, Urlaub H, Jahn R. 2010. Quantitative comparison of glutamatergic and GABAergic synaptic vesicles unveils selectivity for few proteins including MAL2, a novel synaptic vesicle protein. J Neurosci 30: 2-12.

Grunhage F, Schulze TG, Muller DJ, Lanczik M, Franzek E, Albus M, Borrmann-Hassenbach M, Knapp M, Cichon S, Maier W, et al. 2000. Systematic screening for DNA sequence variation in the coding region of the human dopamine transporter gene (DAT1). Mol Psychiatry 5: 275-282.

Guastella J, Nelson N, Nelson H, Czyzyk L, Keynan S, Miedel MC, Davidson N, Lester HA, Kanner BI. 1990. Cloning and expression of a rat brain GABA transporter. Science 249: $1303-1306$

Gundersen V, Shupliakov O, Brodin L, Ottersen OP, StormMathisen J. 1995. Quantification of excitatory amino acid uptake at intact glutamatergic synapses by immunocytochemistry of exogenous D-aspartate. J Neurosci 15: 4417 4428.

Hahn MK, Robertson D, Blakely RD. 2003. A mutation in the human norepinephrine transporter gene (SLC6A2) associated with orthostatic intolerance disrupts surface expression of mutant and wild-type transporters. J Neurosci 23: 4470-4478.

Harkany T, Holmgren C, Hartig W, Qureshi T, Chaudhry FA, Storm-Mathisen J, Dobszay MB, Berghuis P, Schulte G, Sousa KM, et al. 2004. Endocannabinoid-independent retrograde signaling at inhibitory synapses in layer $2 / 3$ of neocortex: Involvement of vesicular glutamate transporter 3. J Neurosci 24: 4978-4988.

Hartinger J, Jahn R. 1993. An anion binding site that regulates the glutamate transporter of synaptic vesicles. J Biol Chem 268: 23122-23127.

Hashimoto K. 2010. Glycine transport inhibitors for the treatment of schizophrenia. Open Med Chem J 4: 10-19.
Haussinger D, Schliess F. 2007. Glutamine metabolism and signaling in the liver. Front Biosci 12: 371-391.

Hell JW, Maycox PR, Jahn R. 1990. Energy dependence and functional reconstitution of the $\gamma$-aminobutyric acid carrier from synaptic vesicles. J Biol Chem 265: 21112117.

Hertting G, Axelrod J, Whitby LG. 1961. Effect of drugs on the uptake and metabolism of ${ }^{3} \mathrm{H}$-norepinephrine. J Pharm Exp Ther 134: 146-153.

Hiesinger PR, Fayyazuddin A, Mehta SQ, Rosenmund T, Schulze KL, Zhai RG, Verstreken P, Cao Y, Zhou Y, Kunz J, et al. 2005. The v-ATPase V0 subunit al is required for a late step in synaptic vesicle exocytosis in Drosophila. Cell 121: 607-620.

Hnasko TS, Chuhma N, Zhang H, Goh GY, Sulzer D, Palmiter RD, Rayport S, Edwards RH. 2010. Vesicular glutamate transport promotes dopamine storage and glutamate corelease in vivo. Neuron 65: 643-656.

Holtje M, Winter S, Walther D, Pahner I, Hortnagl H, Ottersen OP, Bader M, Ahnert-Hilger G. 2003. The vesicular monoamine content regulates VMAT2 activity through Galphaq in mouse platelets. Evidence for autoregulation of vesicular transmitter uptake. J Biol Chem 278: 1585015858.

Horiuchi M, Nicke A, Gomeza J, Aschrafi A, Schmalzing G, Betz H. 2001. Surface-localized glycine transporters 1 and 2 function as monomeric proteins in Xenopus oocytes. Proc Natl Acad Sci 98: 1448-1453.

Ingram SL, Prasad BM, Amara SG. 2002. Dopamine transporter-mediated conductances increase excitability of midbrain dopamine neurons. Nat Neurosci 5: 971-978.

Ishikawa T, Sahara Y, Takahashi T. 2002. A single packet of transmitter does not saturate postsynaptic glutamate receptors. Neuron 34: 613-621.

Jacob G, Robertson RM, Costa F, Wathen MS, Stein M, Black BK, Biaggioni I, Robertson D. 1997. The local norepinephrine spillover in arms and legs of patients with idiopathic orthostatic intolerance: Evidence of partial dysautonomia. In VIII International Symposium on the Autonomic Nervous System, p. 235. Rapid Science Publishers, London.

Jen JC, Wan J, Palos TP, Howard BD, Baloh RW. 2005. Mutation in the glutamate transporter EAAT1 causes episodic ataxia, hemiplegia, seizures. Neurology 65: 529534.

Johnson RG, Carty SE, Scarpa A. 1981. Proton: Substrate stoichiometries during active transport of biogenic amines in chromaffin ghosts. J Biol Chem 256: 5773-5780.

Jones SR, Gainetdinov RR, Wightman RM, Caron MG. 1998. Mechanisms of amphetamine action revealed in mice lacking the dopamine transporter. J Neurosci 18: 1979-1986.

Juge N, Yoshida Y, Yatsushiro S, Omote H, Moriyama Y. 2006. Vesicular glutamate transporter contains two independent transport machineries. J Biol Chem 281: 39499-39506.

Juge N, Muroyama A, Hiasa M, Omote H, Moriyama Y. 2009. Vesicular inhibitory amino acid transporter is a $\mathrm{Cl}-/ \gamma$-aminobutyrate co-transporter. J Biol Chem 284: 35073-35078. 
R.D. Blakely and R.H. Edwards

Juge N, Gray JA, Omote H, Miyaji T, Hara C, Uneyama H, Edwards RH, Nicoll RA, Moriyama Y. 2010. Metabolic control of vesicular glutamate transport and release. $\mathrm{Neu}$ ron 68: 99-112.

Kalandadze A, Wu Y, Robinson MB. 2002. Protein kinase C activation decreases cell surface expression of the GLT-1 subtype of glutamate transporter. Requirement of a carboxyl-terminal domain and partial dependence on serine 486. J Biol Chem 277: 45741-45750.

Kam K, Nicoll R. 2007. Excitatory synaptic transmission persists independently of the glutamate-glutamine cycle. J Neurosci 27: 9192-9200.

Kaneda N, Sasaoka T, Kobayashi K, Kiuchi K, Nagatsu I Kurosawa Y, Fujita K, Yokoyama M, Nomura T, Katsuki M, et al. 1991. Tissue-specific and high-level expression of the human tyrosine hydroxylase gene in transgenic mice. Neuron 6: 583-594.

Katz B. 1971. Quantal mechanism of neural transmitter release. Science 173: 123-126.

Kilic F, Murphy DL, Rudnick G. 2003. A human serotonin transporter mutation causes constitutive activation of transport activity. Mol Pharmacol 64: 440-446.

Kilty JE, Lorang D, Amara SG. 1991. Cloning and expression of a cocaine-sensitive rat dopamine transporter. Science 254: $578-580$.

Kim DK, Lim SW, Lee S, Sohn SE, Kim S, Hahn CG, Carroll BJ. 2000. Serotonin transporter gene polymorphism and antidepressant response. Neuroreport 11: 215-219.

Kim CH, Hahn MK, Joung Y, Anderson SL, Steele AH, Mazei-Robinson MS, Gizer I, Teicher MH, Cohen BM, Robertson D, et al. 2006. A polymorphism in the norepinephrine transporter gene alters promoter activity and is associated with attention-deficit hyperactivity disorder. Proc Natl Acad Sci 103: 19164-19169.

Kish PE, Fischer-Bovenkerk C, Ueda T. 1989. Active transport of $\gamma$-aminobutyric acid and glycine into synaptic vesicles. Proc Natl Acad Sci 86: 3877-3881.

Klassen LJ, Katzman MA, Chokka P. 2010. Adult ADHD and its comorbidities, with a focus on bipolar disorder. J Affect Disord 124: 1-8.

Knoth J, Zallakian M, Njus D. 1981. Stoichiometry of $\mathrm{H}^{+}$linked dopamine transport in chromaffin granule ghosts Biochemistry 20: 6625-6629.

Kohli U, Hahn MK, English BA, Sofowora GG, Muszkat M, Li C, Blakely RD, Stein CM, Kurnik D. 2011. Genetic variation in the presynaptic norepinephrine transporter is associated with blood pressure responses to exercise in healthy humans. Pharmacogenet Genomics 21: 171-178.

Krishnamurthy H, Piscitelli CL, Gouaux E. 2009. Unlocking the molecular secrets of sodium-coupled transporters. Nature 459: 347-355.

Lambert JJ, Delelli D, Hill-Venning C, Peters JA. 1995. Neurosteroids and GABAA receptor function. Trends Pharm Sc 16: 295-303.

Lambert E, Eikelis N, Esler M, Dawood T, Schlaich M, Bayles R, Socratous F, Agrotis A, Jennings G, Lambert G, et al. 2008. Altered sympathetic nervous reactivity and norepinephrine transporter expression in patients with postural tachycardia syndrome. Circ Arrhythm Electrophysiol 1: 103-109.
Lee RY, Sawin ER, Chalfie M, Horvitz HR, Avery L. 1999. EAT-4, a homolog of a mammalian sodium-dependent inorganic phosphate cotransporter, is necessary for glutamatergic neurotransmission in caenorhabditis elegans. J Neurosci 19: 159-167.

Lee FJ, Pei L, Moszczynska A, Vukusic B, Fletcher PJ, Liu F. 2007. Dopamine transporter cell surface localization facilitated by a direct interaction with the dopamine D2 receptor. EMBO J 26: 2127-2136.

Lee S, Kim K, Zhou ZJ. 2010. Role of ACh-GABA cotransmission in detecting image motion and motion direction. Neuron 68: 1159-1172.

Leo S, Moechars D, Callaerts-Vegh Z, D'Hooge R, Meert T. 2009. Impairment of VGLUT2 but not VGLUT1 signaling reduces neuropathy-induced hypersensitivity. Eur $J$ Pain 13: 1008-1017.

Lesch KP, Bengel D, Heils A, Sabol SZ, Greenberg BD, Petri S, Benjamin J, Muller CR, Hamer DH, Murphy DL. 1996. Association of anxiety-related traits with a polymorphism in the serotonin transporter gene regulatory region. Science 274: 1527-1531.

Lima Rde F, Prado VF, Prado MA, Kushmerick C. 2010. Quantal release of acetylcholine in mice with reduced levels of the vesicular acetylcholine transporter. J Neurochem 113: 943-951.

Liu Y, Peter D, Raghani A, Schuldiner S, Prive GG, Eisenberg D, Brecha N, Edwards RH. 1992. A cDNA that suppresses $\mathrm{MPP}^{+}$toxicity encodes a vesicular amine transporter. Cell 70: $539-551$

Macintosh FC, Birks RI, Sastry PB. 1956. Pharmacological inhibition of acetylcholine sythesis. Nature 4543: 11811182.

Madsen KK, White HS, Schousboe A. 2010. Neuronal and non-neuronal GABA transporters as targets for antiepileptic drugs. Pharmacol Ther 125: 394-401.

Mainen ZF, Malinow R, Svoboda K. 1999. Synaptic calcium transients in single spines indicate that NMDA receptors are not saturated. Nature 399: 151-155.

Maire JC, Wurtman RJ. 1985. Effects of electrical stimulation and choline availability on the release and contents of acetylcholine and choline in superfused slices from rat striatum. J Physiol (Paris) 80: 189-195.

Masson J, Darmon M, Conjard A, Chuhma N, Ropert N, Thoby-Brisson M, Foutz AS, Parrot S, Miller GM, Jorisch $\mathrm{R}$, et al. 2006. Mice lacking brain/kidney phosphate-activated glutaminase have impaired glutamatergic synaptic transmission, altered breathing, disorganized goal-directed behavior and die shortly after birth. J Neurosci 26: $4660-4671$.

Mazei-Robison MS, Blakely RD. 2005. Expression studies of naturally occurring human dopamine transporter variants identifies a novel state of transporter inactivation associated with Val382Ala. Neuropharmacology 49: 737749.

Mazei-Robison MS, Bowton E, Holy M, Schmudermaier M, Freissmuth M, Sitte HH, Galli A, Blakely RD. 2008. Anomalous dopamine release associated with a human dopamine transporter coding variant. J Neurosci 28: 7040-7046.

McAllister AK, Stevens CF. 2000. Nonsaturation of AMPA and NMDA receptors at hippocampal synapses. Proc Natl Acad Sci 97: 6173-6178. 
McDonald PW, Hardie SL, Jessen TN, Carvelli L, Matthies DS, Blakely RD. 2007. Vigorous motor activity in Caenorhabditis elegans requires efficient clearance of dopamine mediated by synaptic localization of the dopamine transporter DAT-1. J Neurosci 27: 14216-14227.

McIntire S, Jorgensen E, Horvitz HR. 1993. Genes required for GABA function in Caenorhabditis elegans. Nature 364: 337-341.

McIntire SL, Reimer RJ, Schuske K, Edwards RH, Jorgensen EM. 1997. Identification and characterization of the vesicular GABA transporter. Nature 389: 870-876.

Miyaji T, Echigo N, Hiasa M, Senoh S, Omote H, Moriyama Y. 2008. Identification of a vesicular aspartate transporter Proc Natl Acad Sci 105: 11720-11724.

Morin P, Sagne C, Gasnier B. 2004. Functional characterization of wild-type and mutant human sialin. Embo J 23: 4560-4570.

Mosharov EV, Gong LW, Khanna B, Sulzer D, Lindau M. 2003. Intracellular patch electrochemistry: Regulation of cytosolic catecholamines in chromaffin cells. J Neurosci 23: 5835-5845.

Mosharov EV, Larsen KE, Kanter E, Phillips KA, Wilson K, et al. 2009. Interplay between cytosolic dopamine, calcium, and $\alpha$-synuclein causes selective death of substantia nigra neurons. Neuron 62: 218-229.

Murphy DL, Lesch KP. 2008. Targeting the murine serotonin transporter: Insights into human neurobiology. Nat Rev Neurosci 9: 85-96.

Nadler JV. 1987. Sodium-dependent proline uptake in the rat hippocampal formation: Association with ipsilateralcommissural projections of CA3 pyramidal cells. J Neurochem 49: 1155-1160.

Nakata K, Okuda T, Misawa H. 2004. Ultrastructural localization of high-affinity choline transporter in the rat neuromuscular junction: Enrichment on synaptic vesicles. Synapse 53: 53-56.

Ni B, Rosteck PR, Nadi NS, Paul SM. 1994. Cloning and expression of a cDNA encoding a brain-specific $\mathrm{Na}^{+}$dependent inorganic phosphate cotransporter. Proc Natl Acad Sci 91: 5607-5611.

Noh J, Seal RP, Garver JA, Edwards RH, Kandler K. 2010. Glutamate co-release at GABA/glycinergic synapses is crucial for the refinement of an inhibitory map. Nat Neurosci 13: 232-238.

Novarino G, Weinert S, Rickheit G, Jentsch TJ. 2010. Endosomal chloride-proton exchange rather than chloride conductance is crucial for renal endocytosis. Science 328: 1398-1401.

Ozaki N, Goldman D, Kaye WH, Plotnicov K, Greenberg BD, Lappalainen J, Rudnick G, Murphy DL. 2003. Serotonin transporter missense mutation associated with a complex neuropsychiatric phenotype. Mol Psychiatry 8: 895, 933-896.

Pacholczyk T, Blakely RD, Amara SG. 1991. Expression cloning of a cocaine- and antidepressant-sensitive human noradrenaline transporter. Nature 350: 350-354.

Parsons SM. 2000. Transport mechanisms in acetylcholine and monoamine storage. FASEB J 14: 2423-2434.

Parsons RL, Calupca MA, Merriam LA, Prior C. 1999. Empty synaptic vesicles recycle and undergo exocytosis
Vesicular and Plasma Membrane Transporters

at vesamicol-treated motor nerve terminals. J Neurophysiol 81: 2696-2700.

Pastuszko A, Wilson DF, Erecinska M. 1982. Energetics of $\gamma$-aminobutyrate transport in rat brain synaptosomes. $J$ Biol Chem 257: 7514-7519.

Peter D, Jimenez J, Liu Y, Kim J, Edwards RH. 1994. The chromaffin granule and synaptic vesicle amine transporters differ in substrate recognition and sensitivity to inhibitors. J Biol Chem 269: 7231-7237.

Peter D, Liu Y, Sternini C, de Giorgio R, Brecha N, Edwards RH. 1995. Differential expression of two vesicular monoamine transporters. J Neurosci 15: 6179-6188.

Picollo A, Pusch M. 2005. Chloride/proton antiporter activity of mammalian CLC proteins $\mathrm{ClC}-4$ and ClC-5. $\mathrm{Na}$ ture 436: 420-423.

Pines G, Danbolt NC, Bjoras M, Zhang Y, Bendahan A, Eide L, Koepsell H, Storm-Mathisen J, Seeberg E, Kanner BI. 1992. Cloning and expression of a rat brain L-glutamate transporter. Nature 360: 464-467.

Pollock BG, Ferrell RE, Mulsant BH, Mazumdar S, Miller M, Sweet RA, Davis S, Kirshner MA, Houck PR, Stack JA, et al. 2000. Allelic variation in the serotonin transporter promoter affects onset of paroxetine treatment response in late-life depression. Neuropsychopharmacology 23: 587590.

Pow DV, Robinson SR. 1994. Glutamate in some retinal neurons is derived solely from glia. Neuroscience 60: 355366.

Prasad HC, Zhu CB, McCauley JL, Samuvel DJ, Ramamoorthy S, Shelton RC, Hewlett WA, Sutcliffe JS, Blakely RD. 2005. Human serotonin transporter variants display altered sensitivity to protein kinase $\mathrm{G}$ and 38 mitogen-activated protein kinase. Proc Natl Acad Sci 102: $11545-$ 11550.

Prasad HC, Steiner JA, Sutcliffe JS, Blakely RD. 2009. Enhanced activity of human serotonin transporter variants associated with autism. Philos Trans R Soc Lond B Biol Sci 364: $163-173$.

Price GD, Trussell LO. 2006. Estimate of the chloride concentration in a central glutamatergic terminal: A gramicidin perforated-patch study on the calyx of Held. J Neurosci 26: 11432-11436.

Quick MW. 2003. Regulating the conducting states of mammalian serotonin transporter. Neuron 40: 537-549.

Quick MW, Corey JL, Davidson N, Lester HA. 1997. Second messengers, trafficking-related proteins, and amino acid residues that contribute to the functional regulation of the rat brain GABA transporter GAT1. J Neurosci 17: 2967-2979.

Raj V, Haman KL, Raj SR, Byrne D, Blakely RD, Biaggioni I, Robertson D, Shelton RC. 2009. Psychiatric profile and attention deficits in postural tachycardia syndrome. $J$ Neurol Neurosurg Psychiatry 80: 339-344.

Ramamoorthy S, Blakely RD. 1999. Phosphorylation and sequestration of serotonin transporters differentially modulated by psychostimulants. Science 285: 763-766.

Ramamoorthy S, Giovanetti E, Qian Y, Blakely RD. 1998. Phosphorylation and regulation of antidepressant-sensitive serotonin transporters. J Biol Chem 273: $2458-$ 2466. 
R.D. Blakely and R.H. Edwards

Ramamoorthy S, Samuvel DJ, Buck ER, Rudnick G, Jayanthi LD. 2007. Phosphorylation of threonine residue 276 is required for acute regulation of serotonin transporter by cyclic GMP. J Biol Chem 282: 11639-11647.

Ramamoorthy S, Shippenberg TS, Jayanthi LD. 2011. Regulation of monoamine transporters: Role of transporter phosphorylation. Pharmacol Ther 129: 220-238.

Ren J, Qin C, Hu F, Tan J, Qiu L, Zhao S, Feng G, Luo M. 2011. Habenula "cholinergic" neurons corelease glutamate and acetylcholine and activate postsynaptic neurons via distinct transmission modes. Neuron 69: 445-452.

Renick SE, Kleven DT, Chan J, Stenius K, Milner TA, Pickel VM, Fremeau RT Jr. 1999. The mammalian brain highaffinity L-proline transporter is enriched preferentially in synaptic vesicles in a subpopulation of excitatory nerve terminals in rat forebrain. J Neurosci 19: 21-33.

Rothstein JD, Dykes-Hoberg M, Pardo CA, Bristol LA, Jin L, Kuncl RW, Kanai Y, Hediger MA, Wang YF, Schielke JP, et al. 1996. Knockout of glutamate transporters reveals a major role for astroglial transport in excitotoxicity and clearance of glutamate. Neuron 16: 675-686.

Rothstein JD, Patel S, Regan MR, Haenggeli C, Huang YH, Bergles DE, Jin L, Dykes Hoberg M, Vidensky S, Chung DS, et al. 2005. $\beta$-lactam antibiotics offer neuroprotection by increasing glutamate transporter expression. Nature 433: 73-77.

Rudnick G. 1997. Mechanisms of biogenic amine neurotransmitter transporters. In Neurotransmitter transporters: Structure, function, and regulation (ed. Reith MEA), pp. $73-100$. Humana Press, Totowa, NJ.

Rudnick G, Wall SC. 1992. The molecular mechanism of "ecstasy" [3,4-methylenedioxymethamphetamine (MDMA)]: Serotonin transporters are targets for MDMA-induced serotonin release. Proc Natl Acad Sci 89: 1817-1821.

Samuvel DJ, Jayanthi LD, Bhat NR, Ramamoorthy S. 2005. A role for p38 mitogen-activated protein kinase in the regulation of the serotonin transporter: Evidence for distinct cellular mechanisms involved in transporter surface expression. J Neurosci 25: 29-41.

Sarter M, Parikh V. 2005. Choline transporters, cholinergic transmission and cognition. Nat Rev Neurosci 6: 48-56.

Sawada K, Echigo N, Juge N, Miyaji T, Otsuka M, Omote H, Yamamoto A, Moriyama Y. 2008. Identification of a vesicular nucleotide transporter. Proc Natl Acad Sci 105: 5683-5686.

Schafer MK, Varoqui H, Defamie N, Weihe E, Erickson JD. 2002. Molecular cloning and functional identification of mouse vesicular glutamate transporter 3 and its expression in subsets of novel excitatory neurons. J Biol Chem 277: 50734-50748.

Schallier A, Massie A, Loyens E, Moechars D, Drinkenburg W, Michotte Y, Smolders I. 2009. vGLUT2 heterozygous mice show more susceptibility to clonic seizures induced by pentylenetetrazol. Neurochem Int 55: 41-44.

Scheel O, Zdebik AA, Lourdel S, Jentsch TJ. 2005. Voltagedependent electrogenic chloride/proton exchange by endosomal CLC proteins. Nature 436: 424-427.

Schenck S, Wojcik SM, Brose N, Takamori S. 2009. A chloride conductance in VGLUT1 underlies maximal glutamate loading into synaptic vesicles. Nat Neurosci 12: $156-162$.
Schuske K, Palfreyman MT, Watanabe S, Jorgensen EM. 2007. UNC-46 is required for trafficking of the vesicular GABA transporter. Nat Neurosci 10: 846-853.

Seal RP, Akil O, Yi E, Weber CM, Grant L, Yoo J, Clause A, Kandler K, Noebels JL, Glowatzki E, et al. 2008. Sensorineural deafness and seizures in mice lacking vesicular glutamate transporter 3. Neuron 57: 263-275.

Shannon JR, Flattem NL, Jordan J, Jacob G, Black BK, Biaggioni I, Blakely RD, Robertson D. 2000. Orthostatic intolerance and tachycardia associated with norepinephrinetransporter deficiency. $N$ Engl J Med 342: 541-549.

Sinning S, Musgaard M, Jensen M, Severinsen K, Celik L, Koldso H, Meyer T, Bols M, Jensen HH, Schiott B, et al. 2010. Binding and orientation of tricyclic antidepressants within the central substrate site of the human serotonin transporter. J Biol Chem 285: 8363-8374.

Song H, Ming G, Fon E, Bellocchio E, Edwards RH, Poo M. 1997. Expression of a putative vesicular acetylcholine transporter facilitates quantal transmitter packaging. Neuron 18: 815-826.

Steiner JA, Carneiro AM, Blakely RD. 2008. Going with the flow: Trafficking-dependent and -independent regulation of serotonin transport. Traffic 9: 1393-1402.

Stobrawa SM, Breiderhoff T, Takamori S, Engel D, Schweizer M, Zdebik AA, Bösl MR, Ruether K, Jahn H, Draguhn A, et al. 2001. Disruption of ClC-3, a chloride channel expressed on synaptic vesicles, leads to a loss of the hippocampus. Neuron 29: 185-196.

Storm-Mathisen J, Leknes AK, Bore AT, Vaaland JL, Edminson P, Haug FM, Ottersen OP. 1983. First visualization of glutamate and GABA in neurones by immunocytochemistry. Nature 301: 517-520.

Stuber GD, Hnasko TS, Britt JP, Edwards RH, Bonci A. 2010. Dopaminergic terminals in the nucleus accumbens but not the dorsal striatum corelease glutamate. J Neurosci 30: 8229-8233.

Su A, Mager S, Mayo SL, Lester HA. 1996. A multi-substrate single-file model for ion-coupled transporters. Biophys $J$ 70: 762-777.

Sulzer D, Maidment NT, Rayport S. 1993. Amphetamine and other weak bases act to promote reverse transport of dopamine in ventral midbrain neurons. J Neurochem 60: $527-535$.

Sung U, Apparsundaram S, Galli A, Kahlig KM, Savchenko V, Schroeter S, Quick MW, Blakely RD. 2003. A regulated interaction of syntaxin 1A with the antidepressant-sensitive norepinephrine transporter establishes catecholamine clearance capacity. J Neurosci 23: 1697-1709.

Sutcliffe JS, Delahanty RJ, Prasad HC, McCauley JL, Han Q, Jiang L, Li C, Folstein SE, Blakely RD. 2005. Allelic heterogeneity at the serotonin transporter locus (SLC6A4) confers susceptibility to autism and rigid-compulsive behaviors. Am J Hum Genet 77: 265-279.

Takahashi N, Miner LL, Sora I, Ujike H, Revay RS, Kostic V, Jackson-Lewis V, Przedborski S, Uhl GR. 1997. VMAT2 knockout mice: Heterozygous display reduced amphetamine-conditioned reward, enhanced amphetamine locomotion and enhanced MPTP toxicity. Proc Natl Acad Sci 94: 9938-9943.

Takamori S, Rhee JS, Rosenmund C, Jahn R. 2000. Identification of a vesicular glutamate transporter that defines a 
glutamatergic phenotype in neurons. Nature 407: 189194.

Tani H, Bandrowski AE, Parada I, Wynn M, Huguenard JR, et al. 2007. Modulation of epileptiform activity by glutamine and system A transport in a model of posttraumatic epilepsy. Neurobiol Dis 25: 230-238.

Tecuapetla F, Patel JC, Xenias H, English D, Tadros I, Shah F, Berlin J, Deisseroth K, Rice ME, Tepper JM, et al. 2010. Glutamatergic signaling by mesolimbic dopamine neurons in the nucleus accumbens. J Neurosci 30: 71057110.

Tian N, Petersen C, Kash S, Baekkeskov S, Copenhagen D, Nicoll R. 1999. The role of the synthetic enzyme GAD65 in the control of neuronal $\gamma$-aminobutyric acid release. Proc Natl Acad Sci 96: 12911-12916.

Torres GE, Yao WD, Mohn RR, Quan H, Kim K, Levey AI, Staudinger J, Caron MG. 2001. Functional interaction between monoamine plasma membrane transporters and the synaptic PDZ domain-containing protein PICK1. Neuron 30: 121-134.

Torres GE, Carneiro A, Seamans K, Fiorentini C, Sweeney A, Yao WD, Caron MG. 2003a. Oligomerization and trafficking of the human dopamine transporter. Mutational analysis identifies critical domains important for the functional expression of the transporter. J Biol Chem 278: $2731-2739$.

Torres GE, Gainetdinov RR, Caron MG. 2003b. Plasma membrane monoamine transporters: Structure, regulation and function. Nat Rev Neurosci 4: 13-25.

Van der Kloot W. 2003. Loading and recycling of synaptic vesicles in the Torpedo electric organ and the vertebrate neuromuscular junction. Prog Neurobiol 71: 269-303.

Varga V, Losonczy A, Zemelman BV, Borhegyi Z, Nyiri G, Domonkos A, Hangya B, Holderith N, Magee JC, Freund TF. 2009. Fast synaptic subcortical control of hippocampal circuits. Science 326: 449-453.

Varoqui H, Erickson JD. 1996. Active transport of acetylcholine by the human vesicular acetylcholine transporter. $J$ Biol Chem 271: 27229-27232.

Vaughan RA, Huff RA, Uhl RR, Kuhar MJ. 1997. Protein kinase C-mediated phosphorylation and functional regulation of dopamine transporters in striatal synaptosomes. J Biol Chem 272: 15541-15546.

Verheijen FW, Verbeek E, Aula N, Beerens CE, Havelaar AC Joosse M, Peltonen L, Aula P, Galjaard H, van der Spek PJ, et al. 1999. A new gene, encoding an anion transporter, is mutated in sialic acid storage diseases. Nature Genet 23: 462-465.

Voglmaier SM, Kam K, Yang H, Fortin DL, Hua Z, Nicoll RA, Edwards RH. 2006. Distinct endocytic pathways control the rate and extent of synaptic vesicle protein recycling. Neuron 51: 71-84.

Volz TJ, Farnsworth SJ, King JL, Riddle EL, Hanson GR, Fleckenstein AE. 2007. Methylphenidate administration alters vesicular monoamine transporter-2 function in cytoplasmic and membrane-associated vesicles. J Pharmacol Exp Ther 323: 738-745.

Wallen-Mackenzie A, Gezelius H, Thoby-Brisson M, Nygard A, Enjin A, Fujiyama F, Fortin G, Kullander K. 2006. Vesicular glutamate transporter 2 is required for central respiratory rhythm generation but not for locomotor central pattern generation. J Neurosci 26: 12294-12307.
Wang YM, Gainetdinov RR, Fumagalli F, Xu F, Jones SR, Bock CB, Miller GW, Wightman RM, Caron MG. 1997. Knockout of the vesicular monoamine transporter 2 gene results in neonatal death and supersensitivity to cocaine and amphetamine. Neuron 19: 1285-1296.

Weihe E, Schafer MK, Erickson JD, Eiden LE. 1994. Localization of vesicular monoamine transporter isoforms (VMAT1 and VMAT2) to endocrine cells and neurons in rat. J Mol Neurosci 5: 149-164.

Weston MC, Nehring RB, Wojcik SM, Rosenmund C. 2011. Interplay between VGLUT isoforms and endophilin Al regulates neurotransmitter release and short-term plasticity. Neuron 69: 1147-1159.

Whitby LG, Hertting G, Axelrod J. 1960. Effect of cocaine on the disposition of noradrenaline labelled with tritium. Nature 187: 604-605.

Winter S, Brunk I, Walther DJ, Holtje M, Jiang M, Peter JU, Takamori S, Jahn R, Birnbaumer L, Ahnert-Hilger G. 2005. Go2 $\alpha$ regulates vesicular glutamate transporter activity by changing its chloride dependence. J Neurosci 25 : 4672-4680.

Wojcik SM, Rhee JS, Herzog E, Sigler A, Jahn R, Takamori S, Brose N, Rosenmund C. 2004. An essential role for vesicular glutamate transporter 1 (VGLUT1) in postnatal development and control of quantal size. Proc Natl Acad Sci 101: 7158-7163.

Wojcik SM, Katsurabayashi S, Guillemin I, Friauf E, Rosenmund C, Brose N, Rhee JS. 2006. A shared vesicular carrier allows synaptic corelease of GABA and glycine. Neuron 50: 575-587.

Wolosker H, de Souza DO, de Meis L. 1996. Regulation of glutamate transport into synaptic vesicles by chloride and proton gradient. J Biol Chem 271: 11726-11731.

Wreden CC, Wlizla M, Reimer RJ. 2005. Varied mechanisms underlie the free sialic acid storage disorders. J Biol Chem 280: $1408-1416$.

Yamamura HI, Snyder SH. 1972. Choline: High-affinity uptake by rat brain synaptosomes. Science 178: 626-628.

Yamashita A, Singh SK, Kawate T, Jin Y, Gouaux E. 2005. Crystal structure of a bacterial homologue of $\mathrm{Na}^{+} / \mathrm{Cl}^{-}$ dependent neurotransmitter transporters. Nature 437: 215-223.

Yernool D, Boudker O, Folta-Stogniew E, Gouaux E. 2003. Trimeric subunit stoichiometry of the glutamate transporters from Bacillus caldotenax and Bacillus stearothermophilus. Biochemistry 42: 12981-12988.

Yernool D, Boudker O, Jin Y, Gouaux E. 2004. Structure of a glutamate transporter homologue from Pyrococcus horikoshii. Nature 431: 811-818.

Zalsman G, Huang YY, Oquendo MA, Burke AK, Hu XZ, Brent DA, Ellis SP, Goldman D, Mann JJ. 2006. Association of a triallelic serotonin transporter gene promoter region (5-HTTLPR) polymorphism with stressful life events and severity of depression. Am J Psychiatry 163: $1588-1593$.

Zerangue N, Kavanaugh MP. 1996. Flux coupling in a neuronal glutamate transporter. Nature 383: 634-637.

Zhao Y, Terry D, Shi L, Weinstein H, Blanchard SC, Javitch JA. 2010. Single-molecule dynamics of gating in a neurotransmitter transporter homologue. Nature 465: 188 193. 
R.D. Blakely and R.H. Edwards

Zhou Q, Petersen CCH, Nicoll RA. 2000. Effects of reduced vesicular filling on synaptic transmission in rat hippocampal neurones. J Physiol 525: 195-206.

Zhou FM, Liang Y, Salas R, Zhang L, De Biasi M, Dani JA. 2005. Corelease of dopamine and serotonin from striatal dopamine terminals. Neuron 46: 65-74.

Zhu C, Hewlett W, Feoktistov I, Biaggioni I, Blakely RD. 2004. Adenosine receptor, protein kinase G, and p38 mitogen-activated protein kinase-dependent up-regulation of serotonin transporters involves both transporter trafficking and activation. Mol Pharmacol 65: $1462-$ 1474.

Zhu CB, Carneiro AM, Dostmann WR, Hewlett WA, Blakely RD. 2005. p38 MAPK activation elevates serotonin trans- port activity via a trafficking-independent, protein phosphatase 2A-dependent process. J Biol Chem 280: 1564915658.

Zhu CB, Steiner JA, Munn JL, Daws LC, Hewlett WA, Blakely RD. 2007. Rapid stimulation of presynaptic serotonin transport by a3 adenosine receptors. J Pharmacol Exp Ther 322: 332-340.

Zigmond RE, Schwarzschild MA, Rittenhouse AR. 1989. Acute regulation of tyrosine hydroxylase by nerve activity and by neurotransmitters via phosphorylation. Ann Rev Neurosci 12: 415-461.

Zomot E, Bendahan A, Quick M, Zhao Y, Javitch JA, Kanner BI. 2007. Mechanism of chloride interaction with neurotransmitter: Sodium symporters. Nature 449: 726-730. 


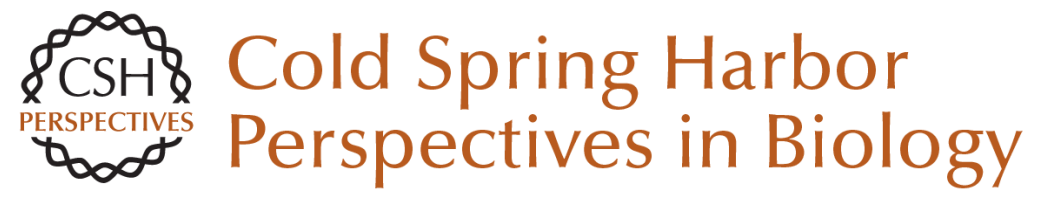

\section{Vesicular and Plasma Membrane Transporters for Neurotransmitters}

Randy D. Blakely and Robert H. Edwards

Cold Spring Harb Perspect Biol 2012; doi: 10.1101/cshperspect.a005595 originally published online December 22, 2011

\section{Subject Collection The Synapse}

Studying Signal Transduction in Single Dendritic Spines Ryohei Yasuda

Synaptic Vesicle Pools and Dynamics AbdulRasheed A. Alabi and Richard W. Tsien

Synapses and Memory Storage Mark Mayford, Steven A. Siegelbaum and Eric $R$. Kandel

Synapses and Alzheimer's Disease Morgan Sheng, Bernardo L. Sabatini and Thomas C. Südhof

Synaptic Cell Adhesion Markus Missler, Thomas C. Südhof and Thomas Biederer

Synaptic Dysfunction in Neurodevelopmental Disorders Associated with Autism and Intellectual Disabilities

Huda Y. Zoghbi and Mark F. Bear

The Postsynaptic Organization of Synapses Morgan Sheng and Eunjoon Kim

Presynaptic LTP and LTD of Excitatory and Inhibitory Synapses

Pablo E. Castillo
Synaptic Vesicle Endocytosis

Yasunori Saheki and Pietro De Camilli

Short-Term Presynaptic Plasticity Wade G. Regehr

NMDA Receptor-Dependent Long-Term

Potentiation and Long-Term Depression

(LTP/LTD) Christian Lüscher and Robert C. Malenka

Ultrastructure of Synapses in the Mammalian

Brain Kristen M. Harris and Richard J. Weinberg

Calcium Signaling in Dendritic Spines Michael J. Higley and Bernardo L. Sabatini

Synaptic Neurotransmitter-Gated Receptors Trevor G. Smart and Pierre Paoletti

Synaptic Vesicle Exocytosis

Thomas C. Südhof and Josep Rizo

Vesicular and Plasma Membrane Transporters for Neurotransmitters

Randy D. Blakely and Robert H. Edwards

For additional articles in this collection, see http://cshperspectives.cshlp.org/cgi/collection/

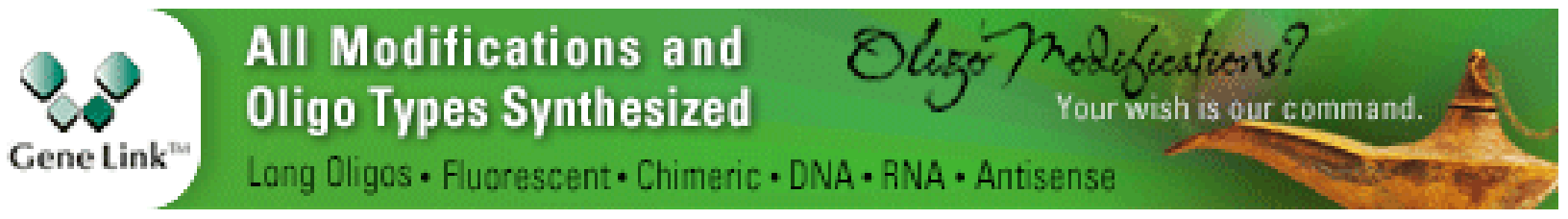

